\title{
Evapotranspiration Studies for Protective Barriers: FY 1988 Status Report
}
S. O. Link
J. L. Downs
M. E. Thiede
W. J. Waugh
R. D. Evans

May 1990

Prepared for the U.S. Department of Energy under Contract DE-AC06-76RLO 1830

Pacific Northwest Laboratory

Operated for the U.S. Department of Energy

by Battelle Memorial Institute 


\title{
DISCLAIMER
}

This report was prepared as an account of work sponsored by an agency of the United States Government. Neither the United States Government nor any agency thereof, nor Battelle Memorial Institute, nor any of their employees, makes any warranty, expressed or implied, or assumes any legal liability or responsibility for the accuracy, completeness, or usefulness of any information, apparatus, product, or process disclosed, or represents that its use would not infringe privatety owned rights. Reference herein to any specific commercial product, process, or service by trade name, trademark, manufacturer, or otherwise, does not necessarily constitute or imply its endorsement, recommendation, or favoring by the United States Government of any agency thereof, or Battelle Memorial institute. The views and opinions of authors expressed herein do not necessarily state or reflect those of the United States Government or any agency thereof.

\author{
PACIFIC NORTHWEST LABORATORY \\ operated by \\ BATTELLE MEMORIAL INSTITUTE \\ for the \\ UNITED STATES DEPARTMENT OF ENERGY \\ under Contract DE-ACO6-76RLO 1830
}

Printed in the United States of America

Available to DOE and DOE contractors from the

Office of Scientific and Technical Information, P.O. Box 62, Oak Ridge, TN 37831; prices avaitable from (615) 576-8401. FTS 626-8401.

Available to the public from the National Technical Information Service,

U.S. Department of Commerce, 5285 Port Royal Rd., Springfield, VA 22161.

NTIS Price Codes, Microfiche A01

Printed Copy

\begin{tabular}{|c|c|c|c|}
\hline Price Code & Page Range & Price Code & Page Range \\
\hline $\mathrm{A} 02$ & $1-10$ & A15 & $326-350$ \\
\hline $\mathrm{A} 03$ & 11. 50 & A16 & $351-375$ \\
\hline $\mathrm{A} 04$ & 51. 75 & A17 & $376-400$ \\
\hline $\mathrm{A} 05$ & $76-100$ & A 18 & $401-425$ \\
\hline$A O 6$ & $101-125$ & A19 & $426-450$ \\
\hline $\mathrm{A} 07$ & $126-150$ & A20 & $451-475$ \\
\hline$A 0 B$ & $151-175$ & A21 & $476-500$ \\
\hline$A 09$ & $176-200$ & $\mathrm{~A} 22$ & $501-525$ \\
\hline $\mathrm{A} 10$ & $201-225$ & A23 & $526-550$ \\
\hline AT1 & $226-250$ & $\mathrm{~A} 24$ & 551.575 \\
\hline A12 & $251-275$ & A25 & $576-600$ \\
\hline A13 & $276-300$ & A99 & 601-Up \\
\hline A14 & $301-325$ & & \\
\hline
\end{tabular}


PNL-6985

UC-702

EVAPOTRANSPIRATION STUDIES FOR PROTECTIVE BARRIERS: FY 1988 STATUS REPORT
S. O. Link
M. E. Thiede
R. D. Evans
J. L. Downs
W. J. Waugh

May 1990

Prepared for

the U.S. Department of Energy

under Contract DE-AC06-76RLO 1830

Pacific Northwest Laboratory Richland, Washington 99352 
- 


\section{EXECUTIVE SUMMARY}

In FY 1988, evapotranspiration studies in support of the Protective Barner Development Program focused on developing instruments to measure evapotranspiration and on conducting natural analog studies.

This status report describes a gas exchange chamber being developed that will control internal temperature and relative humidity to simulate outdoor conditions. This device will measure evapotranspiration rates unambiguously from any surface and measure carbon dioxide exchange rates, which will provide information on plant growth processes. The report also describes ecophysiological experiments that were conducted to determine water and carbon dynamics of shrubs.

Observations of soil water content around individual shrubs indicated less water at the shallow depths and more at the deepest depths around spiny hopsage (Grayia spinosa) than around big sagebrush (Artemisia tridentata). Stem diameter dynamics revealed similar patterns for both species with stem diameter increases in spring and shrinkage in summer. The final stem diameter was greater for $\underline{A}$. tridentata than for G. spinosa. Nondestructive whole-plant-leaf area measurements indicated that A. tridentata produced more leaf area than did $\mathrm{G}$. spinosa. Xylem pressure potential values were much lower by summer for $\underline{G}$. spinosa than for $\underline{A}$. tridentata, indicating significant osmotic adjustment. Net photosynthesis, stomatal conductance, and transpiration were maximal in the spring and declined thereafter for both species. Stomatal conductance declined with increasing vapor pressure gradient for G. spinosa, a result that will aid in model development. These results show response in plant performance to climate and soil variables. Such data are needed for model predictions of plant cover on waste burial sites. 


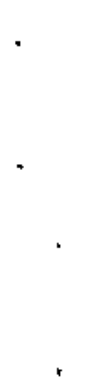




\section{ACKOWLEDGMENTS}

Research described in this report was funded by the U.S. Department of Energy. The authors gratefully acknowledge discussions with Peter Beedlow, Glendon Gee, Randy Kirkham, and Bill Rickard of PNL; the technological developments and innovations for the whole plant gas exchange system of Dave Lettau; and the technical assistance of Jo Harris. 


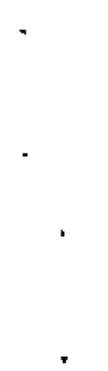




\section{CONTENTS}

EXECUTIVE SUMMARY $\ldots \ldots \ldots \ldots \ldots \ldots \ldots \ldots \ldots \ldots$ iii

ACKNOWLEDGMENTS $\ldots \ldots \ldots \ldots \ldots \ldots \ldots \ldots \ldots \ldots$

1.0 INTRODUCTION $\ldots \ldots \ldots \ldots \ldots \ldots \ldots \ldots \ldots \ldots \ldots \ldots \ldots \ldots \ldots . \ldots \ldots$

2.0 WHOLE PLANT GAS EXCHANGE SYSTEM . . . . . . . . . . . . 2.1

2.1 SYSTEM DEVELOPMENT AND TESTING $\ldots \ldots \ldots \ldots \ldots \ldots \ldots$

3.0 MCGEE PLANT WATER RELATIONS $\ldots \ldots \ldots \ldots \ldots \ldots \ldots \ldots . \ldots \ldots$

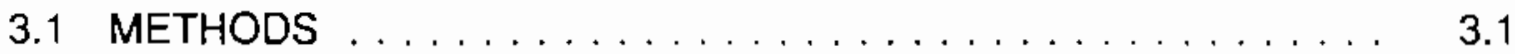

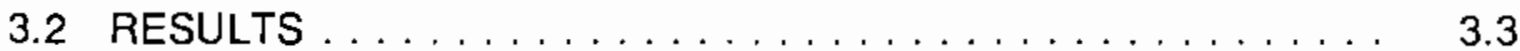

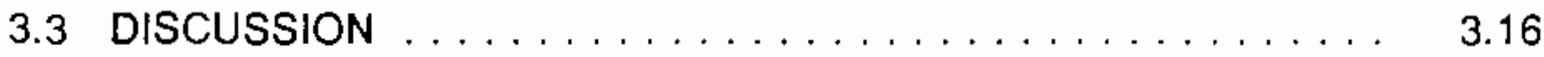

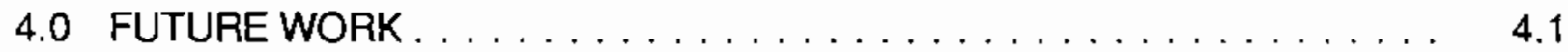

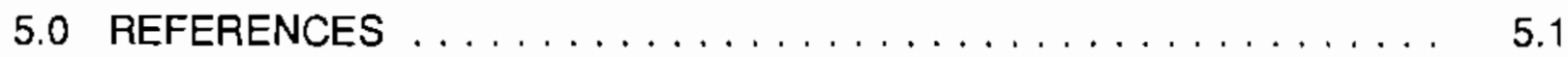




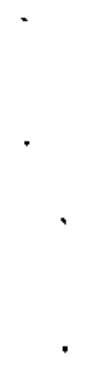




\section{FIGURES}

2.1 Gas Flow and Conditioning for the Air Compressor Component of the Whole Plant Gas Exchange System $\ldots \ldots \ldots \ldots \ldots \ldots . \ldots \ldots$

2.2 Gas Flow Pattern After the Air Compressor for the Whole Plant Gas Exchange System . . . . . . . . . . . . . . . . . . . . 2.2

2.3 Power Supply Designations for the Whole Plant Gas Exchange System . $\quad 2.3$

2.4 Control Signals from the Computer for the Whole Plant Gas Exchange

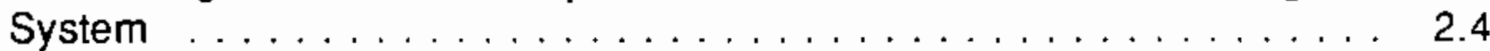

2.5 Sensor Signals for the Whole Plant Gas Exchange System . . . . . . . 2.5

3.1 Meteorological Data at McGee Ranch for Days 70 to 194 at 2:00 p.m. at a Height of $2 \mathrm{~m} \ldots \ldots \ldots \ldots \ldots \ldots \ldots \ldots \ldots$

3.2 Average Soil Water Content with Depth for Randomly Placed Holes in the Plant Community . . . . . . . . . . . . . . . . . . . . . . . .

3.3 Average Soil Water Content with Depth Around the First Individual A. tridentata Plant . . . . . . . . . . . . . . . . . . . . . . . . 3.6

3.4 Average Soil Water Content with Depth Around the Second Individual $A$. tridentata Plant

3.5 Average Soil Water Content with Depth Around G. spinosa . . . . . . . . 3.8

3.6 Change in Stem Diameter on Three A. tridentata Plants . . . . . . . . . 3.9

3.7 Change in Stem Diameter on Three $\mathrm{G}$. spinosa Plants . . . . . . . . . . 3.10

3.8 Average Percent Increase of Leaf Area for A. tridentata and G. spinosa . 3.11

3.9 Average Xylem Pressure Potential for A. tridentata and G. spinosa at Midday from March to July . . . . . . . . . . . . . . . . . . . . . 3.12

3.10 Average Osmotic Potential for A. tridentata and $\mathrm{G}$. spinosa at Midday from March to July 
3.11 Average Turgor Pressure for $\mathrm{A}$. tridentata and $\mathrm{G}$. spinosa

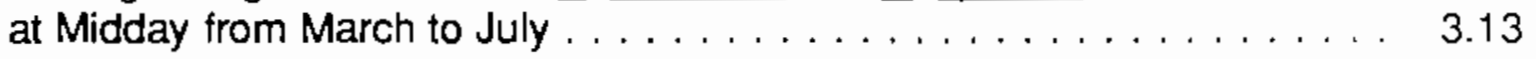

3.12 Average Net Photosynthesis for $A$. tridentata and $\mathrm{G}$. spinosa at Midday from March to July . . . . . . . . . . . . . . . . . . 3.13

3.13 Average Stomatal Conductance for $A$. tridentata and $\mathrm{G}$. spinosa at Midday from March to July . . . . . . . . . . . . . . . . . . 3.14

3.14 Average Transpiration for $\mathrm{A}$. tridentata and $\mathrm{G}$. spinosa

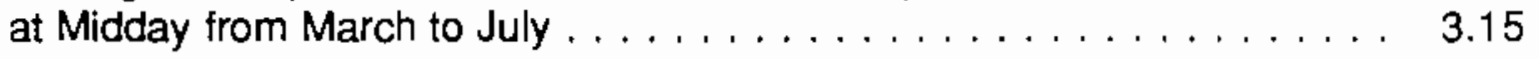

3.15 Effect of Vapor Pressure Gradient on Net Photosynthesis of $\mathrm{G}$. spinosa .

3.16 Effect of Vapor Pressure Gradient on Stomatal Conductance

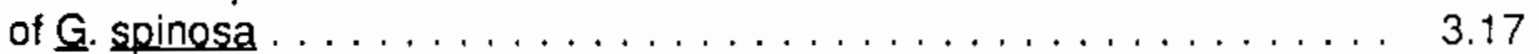

3.17 Effect of Vapor Pressure Gradient on Transpiration of $\mathbf{G}$. spinosa . . . . 3.18

3.18 Effect of Vapor Pressure Gradient on Intemal $\mathrm{CO}_{2}$ of $\mathrm{G}$. spinosa $\ldots \ldots \quad 3.18$

3.19 Effect of Vapor Pressure Gradient on Water-Use Efficiency of $\mathrm{G}$. spinosa . 


\subsection{INTRODUCTION}

The main purpose of the barrier to be constructed over waste sites on the Hanford Site is to reduce the likelihood that plants, animals, and water would come in contact with the waste. Evapotranspiration studies conducted by Pacific Northwest Laboratory (PNL) in support of barner development focused on preventing water drainage into the waste. These investigations are important because water can enter the barrier as precipitation and leave by evapotranspiration; any water that is not lost by evapotranspiration potentially can enter the waste by drainage.

As stated in the test plan (Link and Waugh 1989), specific objectives of PNL's evapotranspiration work were to:

- develop and test an environmentally controlled whole-plant gas exchange system

- collect evapotranspiration data at the whole-plant level on the small-tube lysimeters

- collect tranpiration data on shrubs at McGee Ranch

- collect data necessary to parameterize the plant component of the UNSAT-H code.

This report describes the status of the whole plant gas exchange system development through August 1988 and provides results of the ecophysiological experiments carried out at McGee Ranch in 1988. 



\subsection{WHQLE PLANT GAS EXCHANGE SYSTEM}

\subsection{SYSTEM DEVELOPMENT AND TESTING}

A detailed description of the whole plant gas exchange system is found in Link and Waugh (1989). Schematics for a single chamber system are given in Figures 2.1 through 2.5. An instrument-grade air compressor system to supply air to the whole plant gas exchange system has been completed. It will be tested when the remainder of the system has been developed. All other instruments required to operate the system have been developed, except for the data acquisition and control boards, which have been ordered. When parts arrive, the system will be tested. The temperature control capability of the chamber has been tested in the laboratory and found to remain within $1^{\circ} \mathrm{C}$ of the set point temperature. With new software planned for use, this amount of error should be reduced.

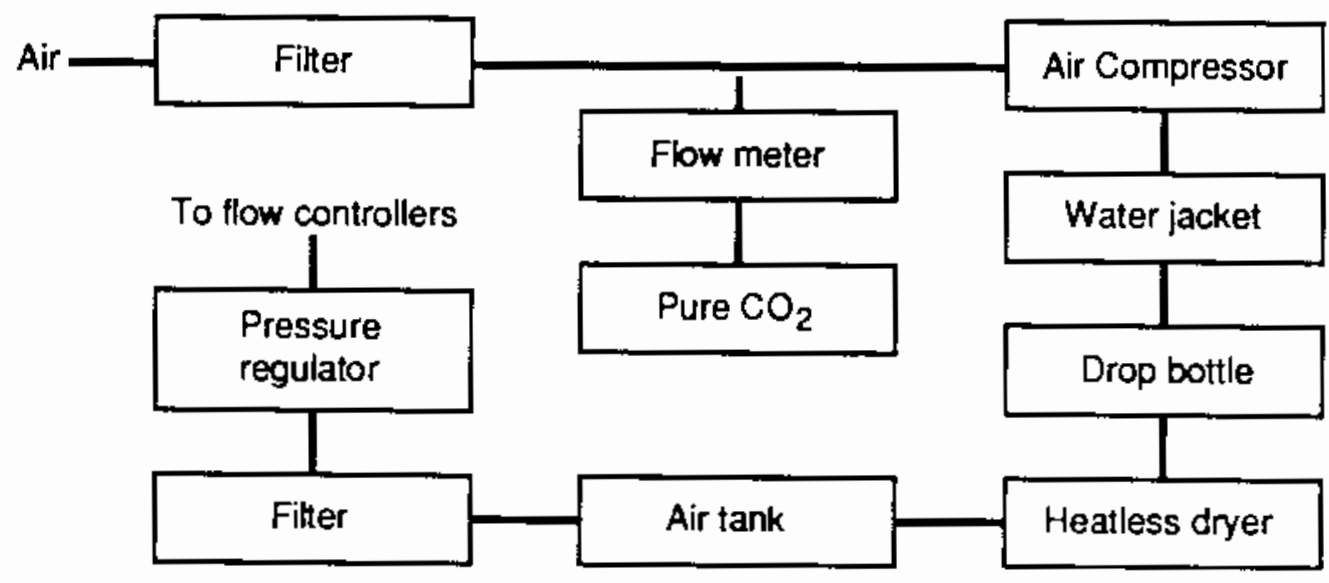

FIGURE 2.1. Gas Flow and Conditioning for the Air Compressor Component of the Whoie Plant Gas Exchange System 


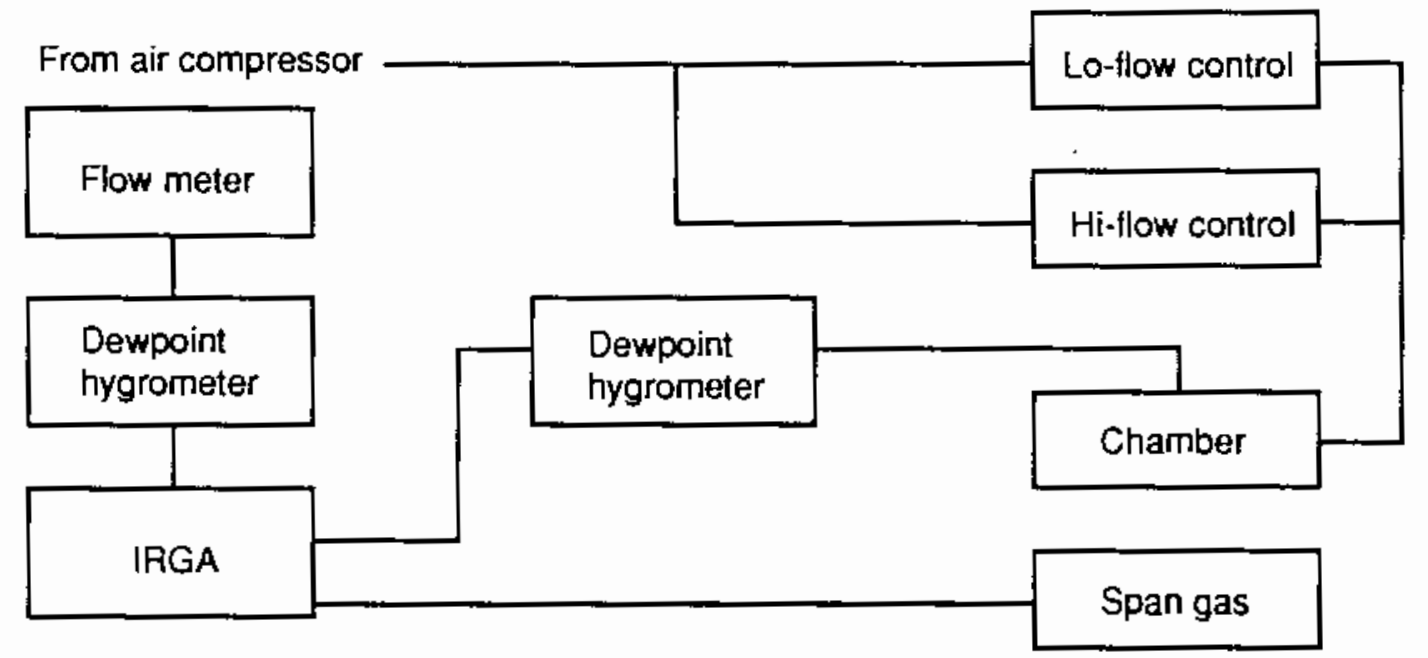

FIGURE 2.2. Gas Flow Pattern After the Air Compressor for the Whole Plant Gas Exchange System 


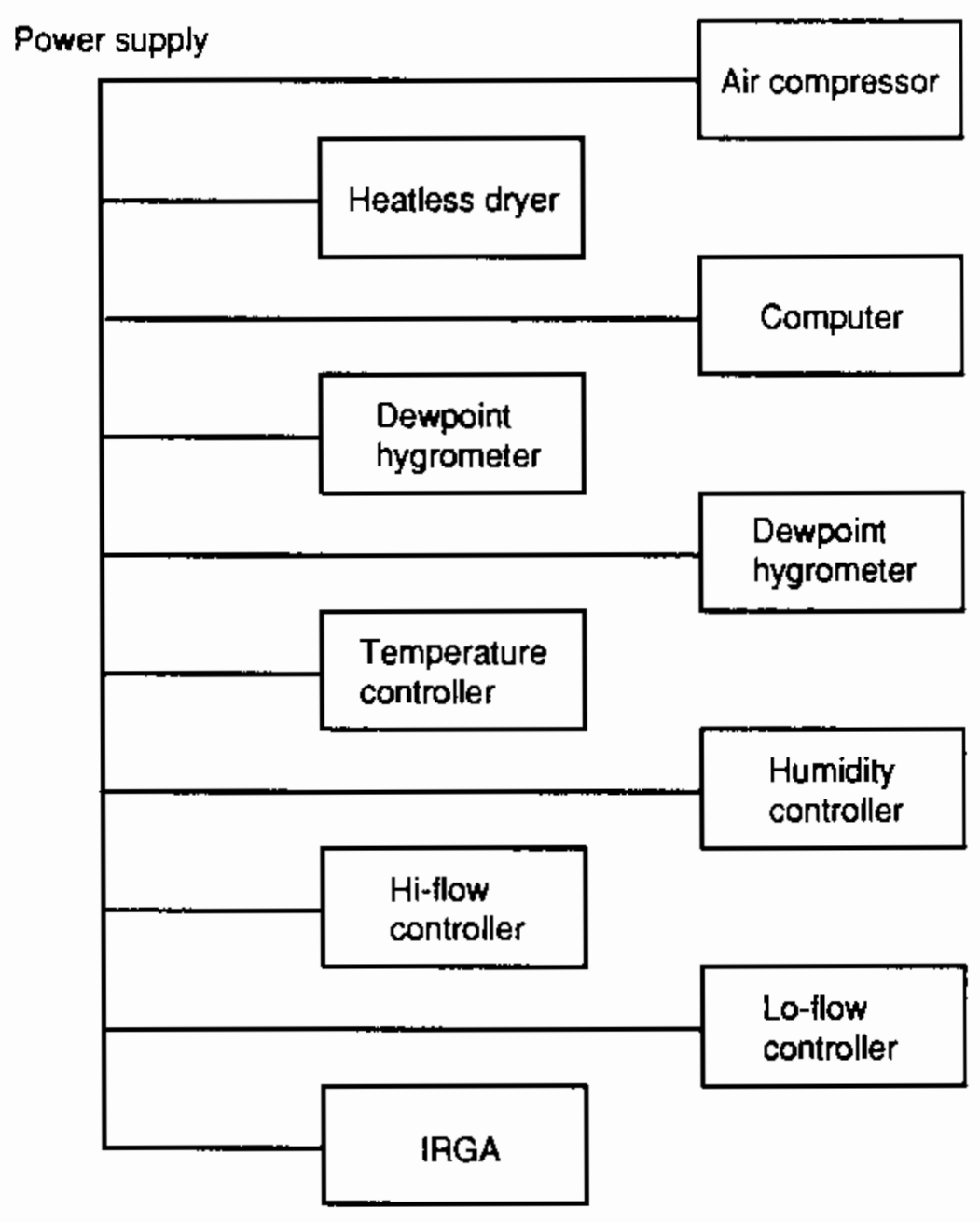

FlGURE 2.3. Power Supply Designations for Whole Plant Gas Exchange System 


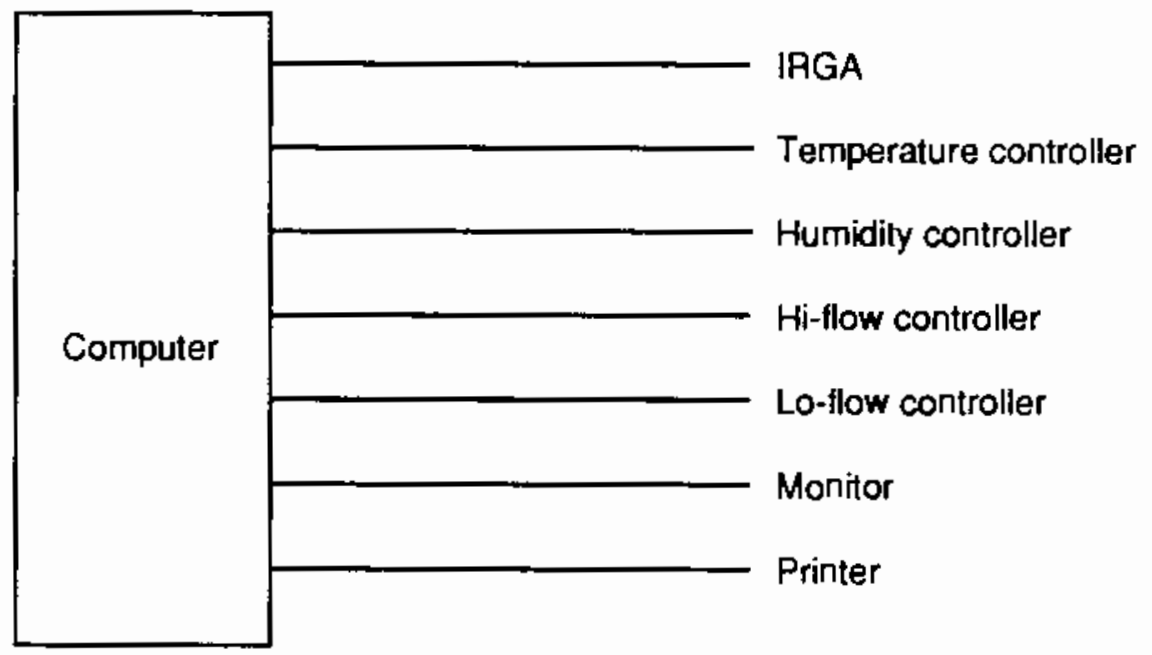

FIGURE 2.4. Control Signals from the Computer for the Whole Plant Gas Exchange System 


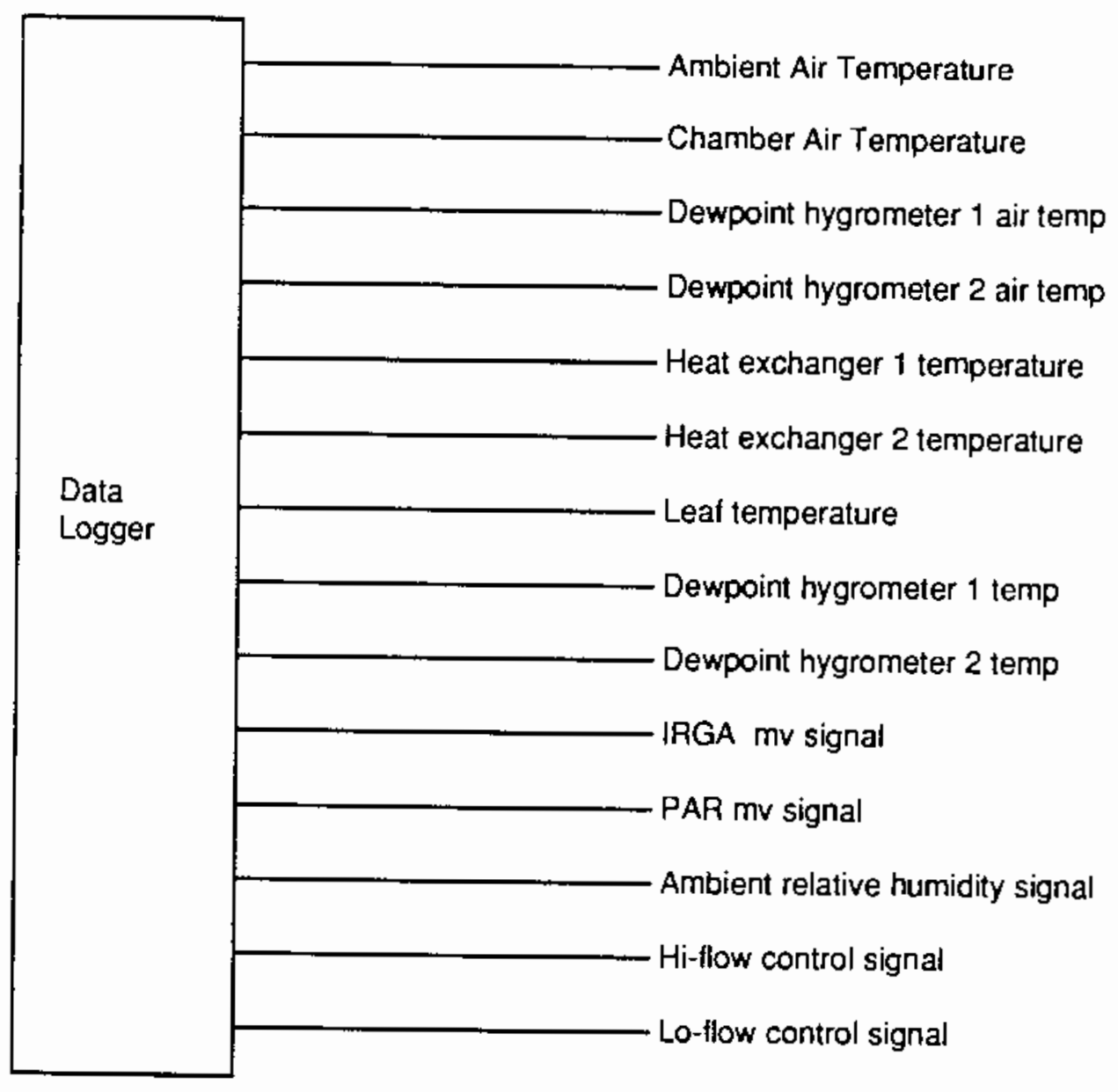

FIGURE 2.5. Sensor Signals for the Whole Plant Gas Exchange System 



\subsection{MCGEE PLANT WATER RELATIONS}

The objective of this study was to characterize transpiration, photosynthesis, plant water relations, leaf area, growth, and soil water status during late winter 1987 to early summer 1988. The procedures followed to accomplish these tasks and the resuits found are described in this section. Results from the characterization will be used to improve the plant component of the UNSAT-H code and will form the basis for a comparison between the undisturbed vegetation of McGee Ranch and the newly established plants located on the large lysimeters of the Field Lysimeter Test Facility. Work done at the site in 1986 is summanized in Link and Waugh (1989).

\subsection{METHODS}

Soil water measurements were taken in March and July using a neutron probe at depths of $30,45,80,125,175,225$, and $275 \mathrm{~cm}$ in each of 24 holes. Six of the holes were randomly located in the study area with the remaining 18 located around shrubs. Around each shrub, holes were located at $90^{\circ}$ angles from one another with four located closer to the shrub and four farther away. One $\underline{G}$. spinosa shrub and two $\underline{A}$. tridentata shrubs were observed.

Growth was monitored by observing changes in stem diameter with CERES devices (Beedlow, Daly, and Thiede 1986). The devices described in Beedlow, Daly, and Thiede (1986) were sensitive to temperature, requiring a correction factor, while devices used in this study were temperature insensitive. This conclusion was reached by conducting a calibration experiment where diameter and temperature were varied and tested for the significance of linear regression parameters for temperature in the relationship between the millivolt signal from the device and associated widths $(\mathrm{mm})$ in the following equation:

$$
Y=b_{0}+b_{1}{ }^{*} X+b_{2}{ }^{*} T+b_{3}{ }^{*} X^{*} T
$$


where $Y=$ stem diameter $(\mathrm{mm})$

$X=$ associated millivolt signal

$T=$ temperature of the CERES unit

$b_{i}=$ linear regression parameters

The only parameters that were significantly different from 0 were $b_{0}$ and $b_{1}$. The $T$ scores for $b_{2}$ and $b_{3}$ were greater than 0.3 , having probability levels greater than 0.7 . Data from the CERES units were collected and stored with a Campbell Scientific CR7-X data aquisition system hourly from March through July on three individuals of each species.

Non-destructive leaf area dynamics were observed with an automated point frame as described in Caldwell et al. (1983). Observations were taken in March and May on the same three individuals of each species yielding whole plant leaf area values.

Plant water status was determined with a pressure bomb (Soil Water Equipment Co., Corvallis, OR) (Scholander et al. 1965) and with a psychrometer (Decagon Devices, Pullman, WA). Pressure water status data were collected at midday in March, April, May, and July in conjunction with gas exchange observations. Six individuals of each species were observed. Observations were taken on stem tips of about $10 \mathrm{~cm}$ in length. Xylem pressure potential data were obtained by placing cut stems in the pressure bomb chamber, where a wet paper towel was used to maintain a humid atmosphere around the stem and leaf material. Then the chamber was slowly pressurized with nitrogen gas until the tip of the stem first showed evidence of a color change from expressed water. Leaves were stripped from the stems, placed in Tygon tubing, capped, and placed on dry ice for the subsequent determination of osmotic potential values with the psychrometer. Turgor pressure was computed as follows:

$$
\psi_{p}=\psi_{\text {tot }}-\psi_{\pi}
$$


where $\psi_{p}$ is the turgor potential, $\psi_{\text {tot }}$ is the xylem pressure potential, and $\psi_{\pi}$ is the osmotic potential.

Gas exchange data were gathered with a null-balance gas exchange system (DDG Co., La Jolla, CA), which yielded information on net photosynthesis, stomatal conductance, transpiration, internal $\mathrm{CO}_{2}$ concentrations, and water-use efficiency. Data on net photosynthesis, stomatal conductance, and transpiration were gathered in March, April, May, and July, 1988, on three individuals of each species. The same individuals were observed each month. Standard conditions of light (full sun), leaf temperature $\left(30^{\circ} \mathrm{C}\right)$, and relative humidity $(20 \%)$ were maintained in the exposure chamber for all observations. In a separate experiment, the effect of vapor pressure gradient on the five gas exchange variables was determined for $\mathrm{G}$. spinosa in April under conditions of full sun and a leaf temperature of $20^{\circ} \mathrm{C}$. All rates were expressed on a leaf-area basis. Leaf-area values were obtained with a Licor-3100 leaf area meter (Licor, Inc., Lincoin, NE).

\subsection{RESULTS}

\subsubsection{Meteorological Observations}

Air temperature, relative humidity, and wind speed at 2:00 p.m. and total daily precipitation are presented for days 70 to 194 . Air temperature ranged from $6^{\circ} \mathrm{C}$ early in the season to $37^{\circ} \mathrm{C}$ in late June (Figure $3.1 \mathrm{a}$ ). Relative humidity ranged from $10 \%$ in late June to $85 \%$ during a rainy day in April (Figure $3.1 \mathrm{~b}$ ). The highest humidity values were associated with precipitation. Wind speed ranged from $2 \mathrm{~m} \mathrm{~s}^{-1}$ to a maximal value of $25 \mathrm{~m} \mathrm{~s}^{-1}$ in late March (Figure 3.1c). Precipitation events only exceeded $0.4 \mathrm{~cm}$ on one day when $0.85 \mathrm{~cm}$ fell (Figure $3.1 \mathrm{~d}$ ). Precipitation occurred during three periods: days 80 to 93,108 to 120 , and 146 to 158 .

\subsubsection{Soil Water}

Volumetric soil water content was higher at all depths on March 27 than on July 11 . To obtain a community-wide estimate of soil water contents, six holes were 

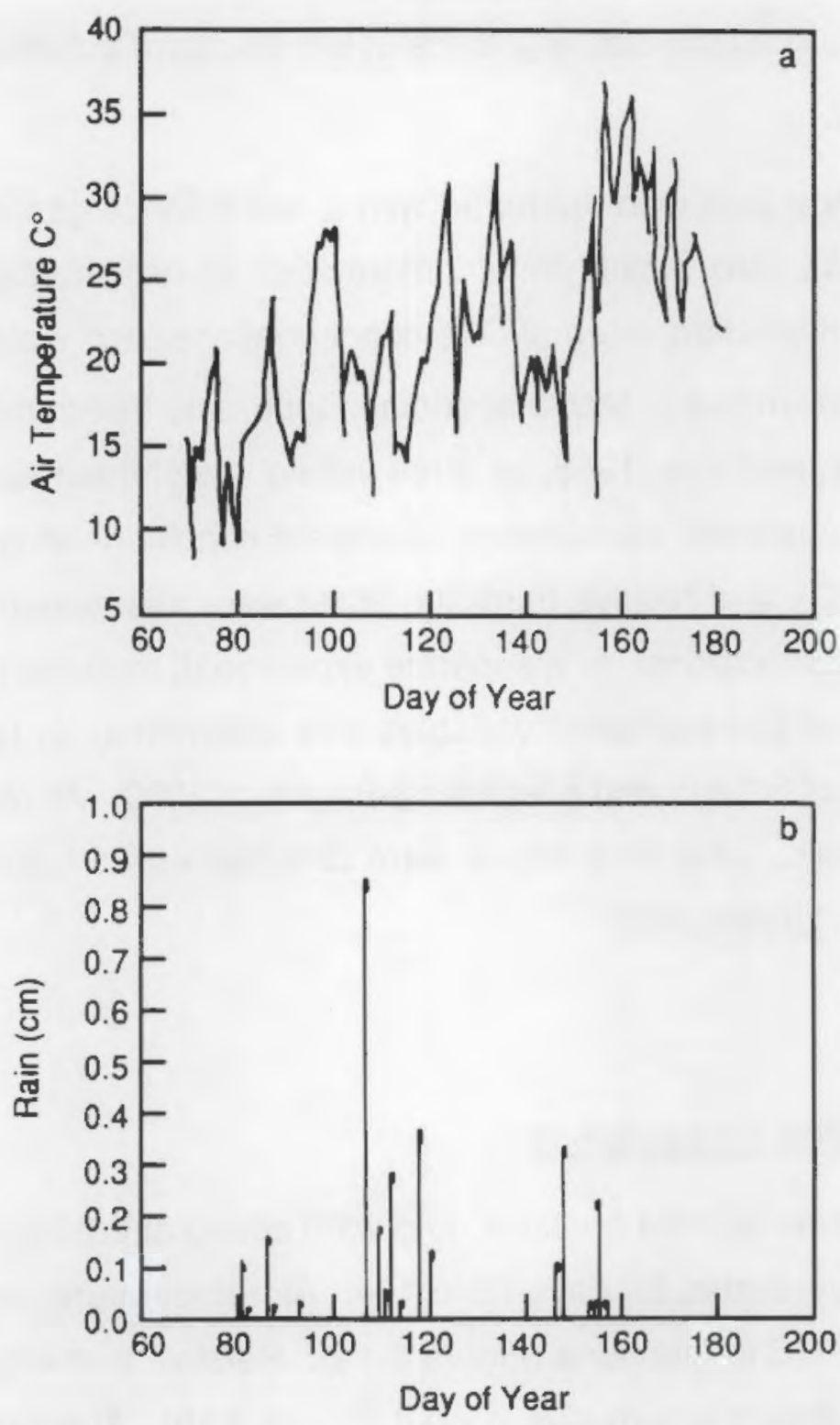

FIGURE 3.1. Meteorological Data at McGee Ranch for Days 70 to 194 at 2:00 p.m. at a Height of $2 \mathrm{~m}$, (a) Air Temperatures, (b) Total Daily Precipitation from Day 80 to Day 160 . There was no precipitation from day 70 to day 80 or from day 160 to day 194.

randomly located in the community (Figure 3.2). On March 27, soil water content was the greatest $(14 \%)$ at the $45-\mathrm{cm}$ depth, falling to between 6 and $8 \%$ for lower depths. On July 11 , soil water content was between 5 and $7 \%$ at all depths. The greatest change in soil water content for the two dates occurred at 30 and $45 \mathrm{~cm}$. At all lower 


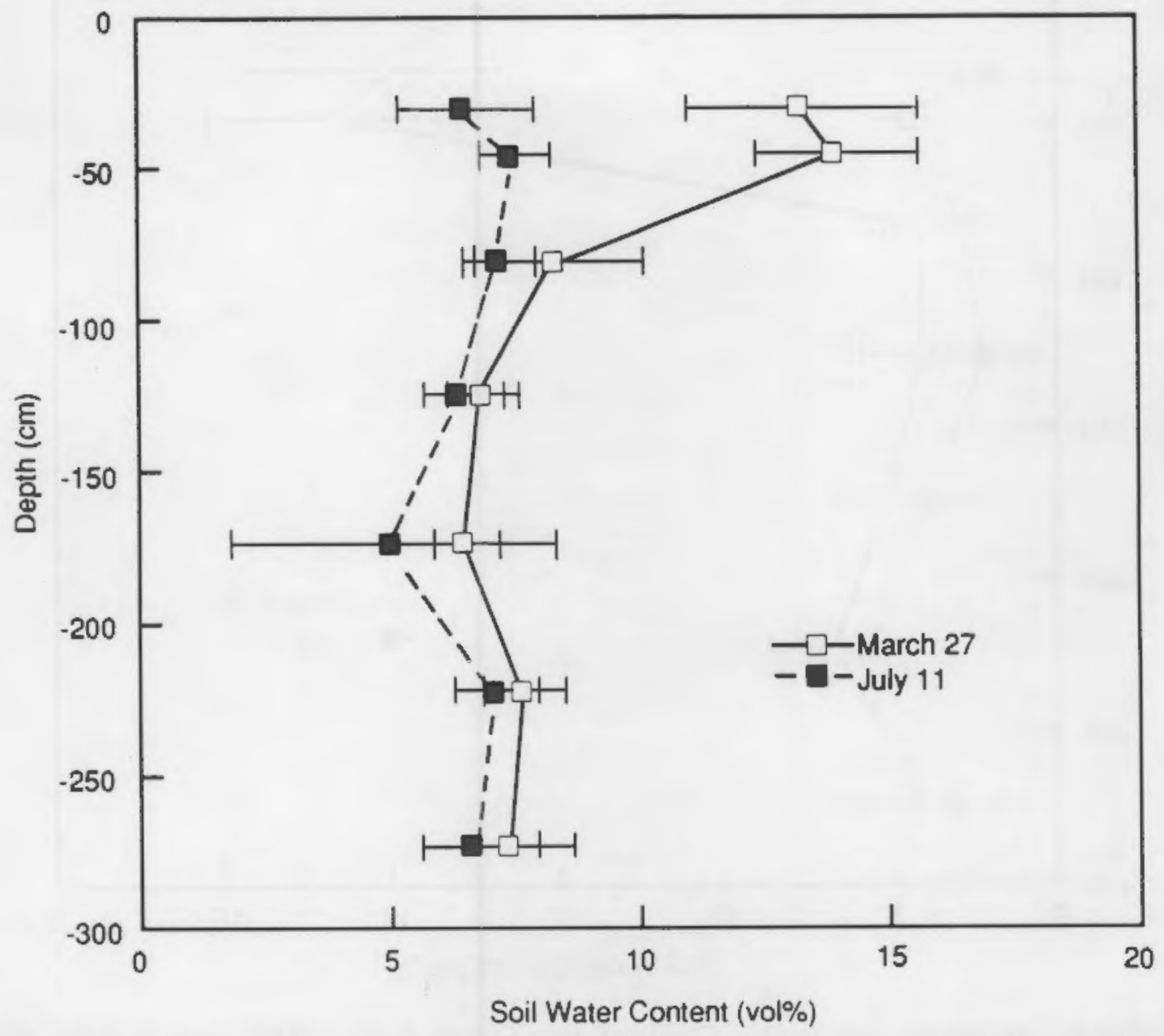

FIGURE 3.2. Average Soil Water Content with Depth for Randomly Placed Holes in the Plant Community. Error bars are one standard error of the mean $(n=6)$.

depths, soil water contents were apparently lower in July than in March, but the difference was not significant at any depth.

To obtain information on the influence of heterogeneity in the plant community on soil water content, eight holes were randomly located around each of two individual $A$. tridentata plants and one $\underline{\mathrm{G}}$. spinosa plant, and soil water content was measured at several depths on March 27 and July 11 . Soil water content around the first $A$.

tridentata (Figure 3.3) was between 14 and $15 \%$ at 30 and $45 \mathrm{~cm}$ and between 7 and $9 \%$ for lower depths on March 27 . By July 11 , soil water content at 30 and $45 \mathrm{~cm}$ had 


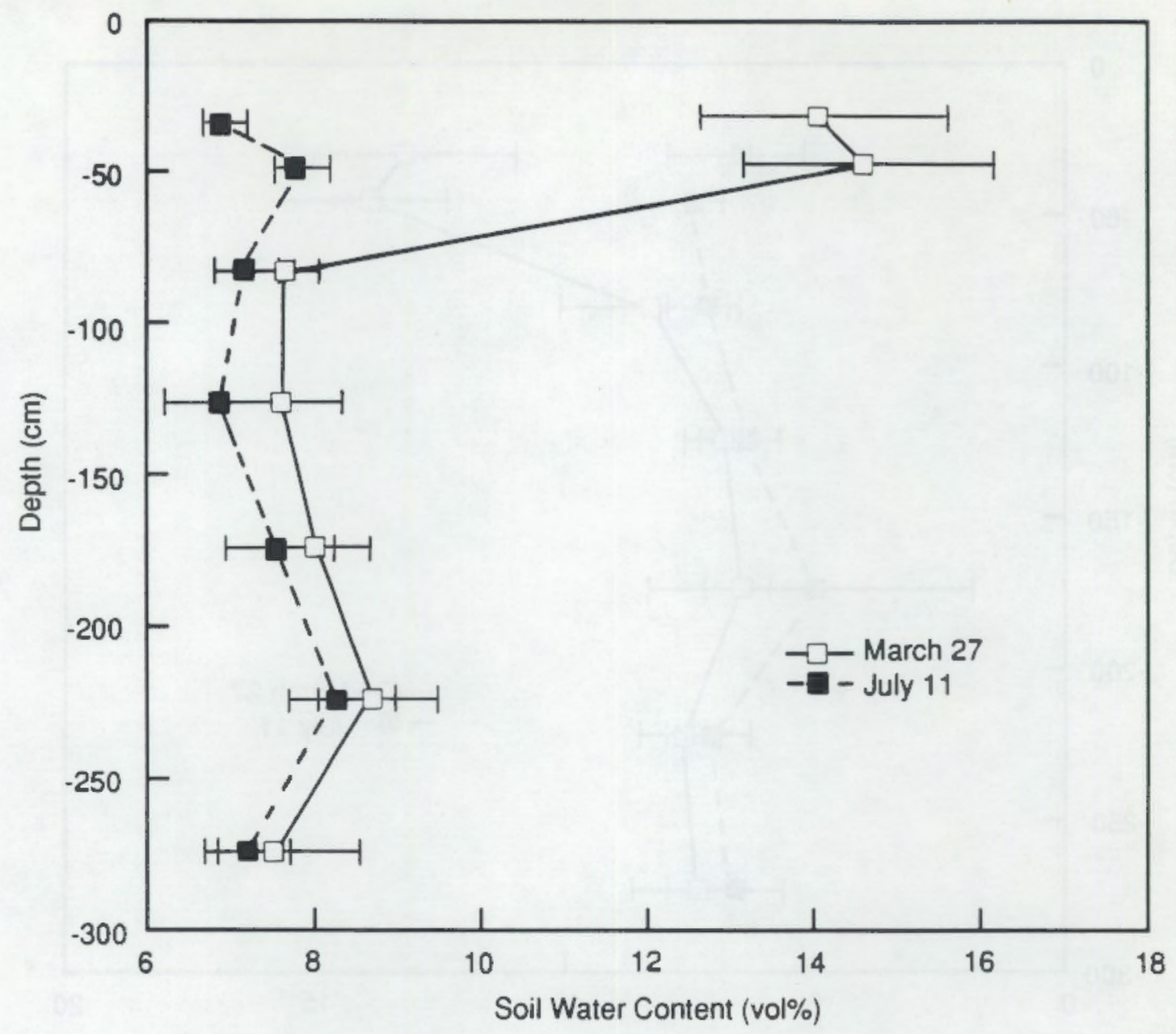

FIGURE 3.3. Average Soil Water Content with Depth Around the First Individual A. tridentata Plant. Error Bars are one standard error of the mean $(n=8)$.

fallen to between 7 and $8 \%$, the same as the water content at lower depths. Soil water content around the second $A$. tridentata (Figure 3.4) was between 13 and $14 \%$ at 30 and $45 \mathrm{~cm}, 11 \%$ at $80 \mathrm{~cm}$, and 9 and $11 \%$ at the lower depths. By July 11 , soil water content at 30,45 , and $80 \mathrm{~cm}$ had fallen to between 7 and $8 \%$ and had fallen to between 8 and $10 \%$ at lower depths. Soil water content around the $\mathrm{G}$. spinosa individual (Figure 3.5) was between 12 and $13 \%$ at 30 and $45 \mathrm{~cm}$, falling to about $8.5 \%$ at $80 \mathrm{~cm}$, and to a low of about $6.5 \%$ at $175 \mathrm{~cm}$. At the two lowest depths, soil water content was between 8 and $9 \%$. By July 11 , soil water content had fallen to 


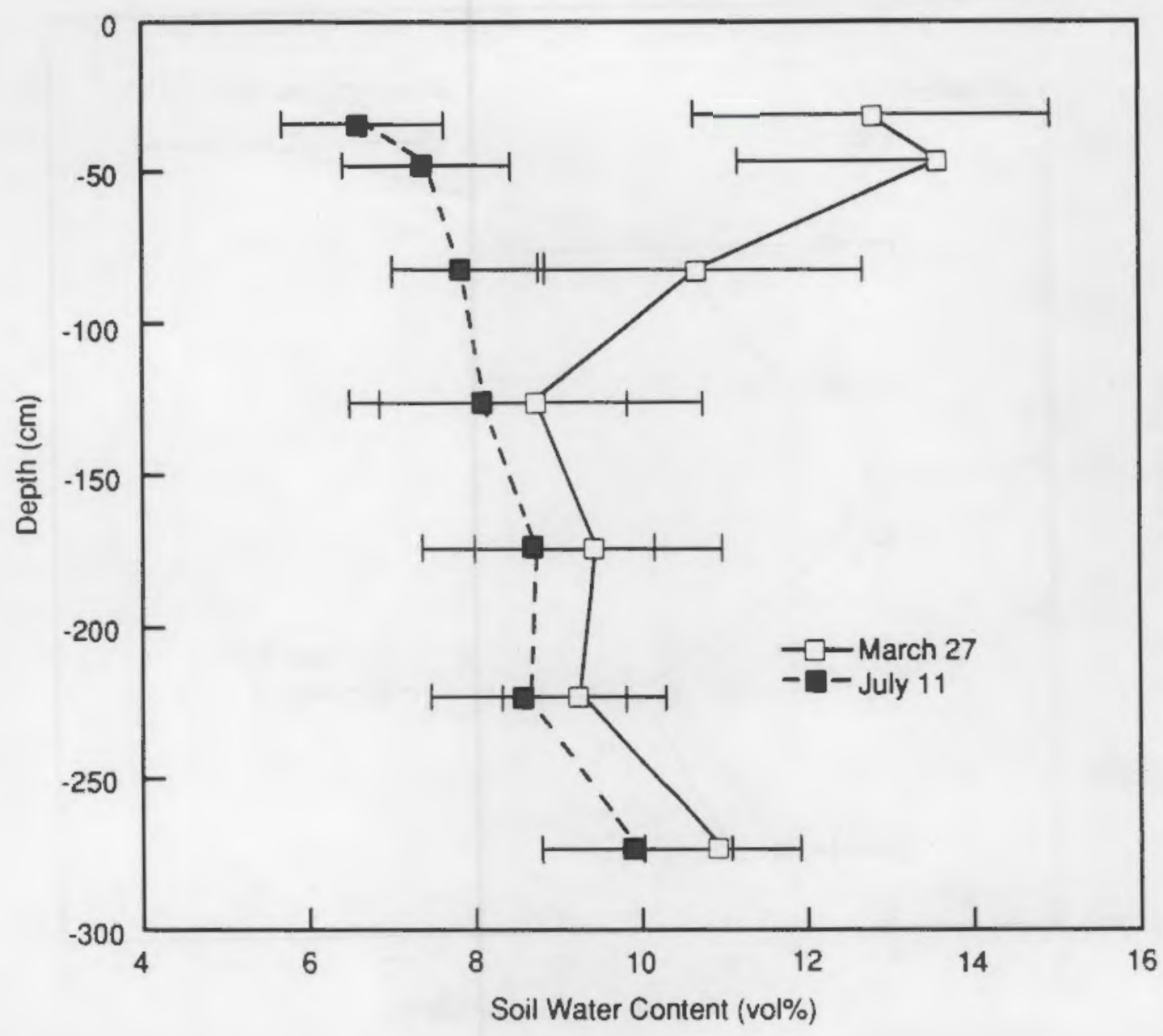

FIGURE 3.4. Average Soil Water Content with Depth Around the Second Individual A. tridentata Plant. Error bars are one standard error of the mean $(n=8)$.

between 5 and $7 \%$ for all but the two lowest depths, which were between 7 and $9 \%$. On both dates, there appeared to be significantly less water at $175 \mathrm{~cm}(\sim 6 \%)$ than at $225 \mathrm{~cm}(\sim 9 \%)$.

Significant differences were evident between the two $A$. tridentata plants and between the two species. The main difference between the two $A$. tridentata plants was that on both days the soil water content of the first plant below $45 \mathrm{~cm}$ was about $1 \%$ less than for the second plant. Two differences between $\underline{\mathrm{G}}$. spinosa and the two $\underline{A}$. tridentata plants were observed. First, significantly less water occurred at $30 \mathrm{~cm}$ on 


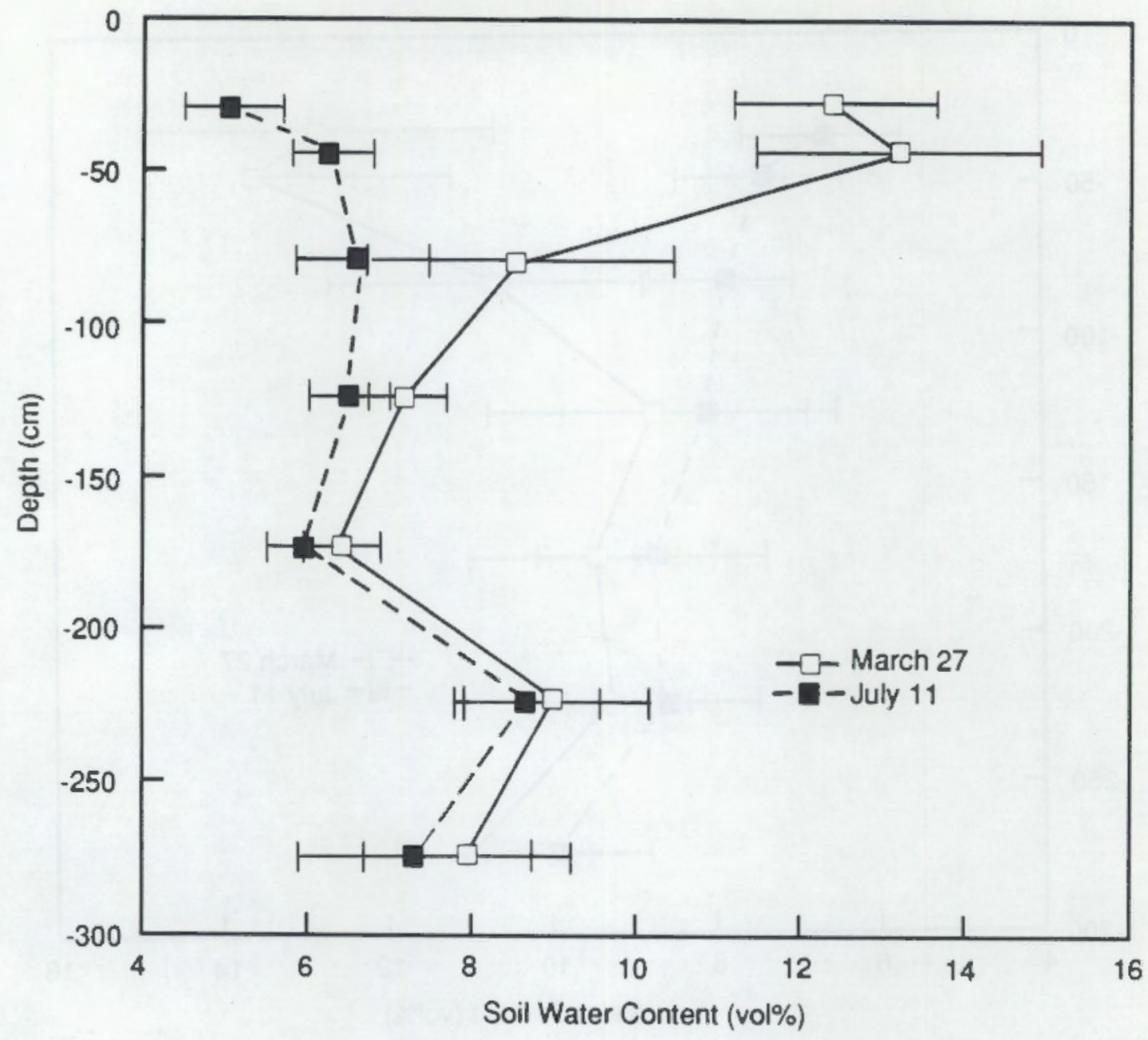

FIGURE 3.5. Average Soil Water Content with Depth Around G. spinosa. Error bars are one standard error of the mean $(n=8)$.

July 11 for $\underline{G}$. spinosa (5\%) than for the two $A$. tidentata plants $(\sim 7 \%)$. Second, significantly more water occurred at $225 \mathrm{~cm}$ than at $175 \mathrm{~cm}$ for $\underline{G}$. spinosa. No water was evident for the two $\underline{A}$. tridentata plants.

\subsubsection{Stem Growth}

The dynamics of stem-diameter growth were observed for three individuals of both species between days 67 and 203 with the CERES device. Observations on A. tridentata indicated that after an initial stem shrinkage, until day 72 , the diameter of the stems increased until day 137 , after which stem diameters again decreased 
(Figure 3.6). Final stem diameters were all greater than the initial diameters with the change in stem diameter ranging from 0.04 to $0.37 \mathrm{~mm}$. Observations on $\underline{\mathrm{G}}$. spinosa indicated again initial stem shrinkage until day 72 , with a maximal value on day 129 , and shrinkage thereafter (Figure 3.7). Final stem diameters were greater than the initial diameters for two $(0.08$ and $0.13 \mathrm{~mm})$ of the three individuals, while the stem of the third individual died. Two differences between the species are apparent. Maximal stem diameter occurred later for $A$. tridentata (day 137) than for $G$. spinosa (day 129), and the average final stem diameter increase was greater for $\underline{A}$. tridentata $(0.23 \mathrm{~mm})$ than for $G$. spinosa $(0.11 \mathrm{~mm})$. The periodic spikes on the graphs of stem diameter all occur in association with precipitation events (Figure 3.1d).

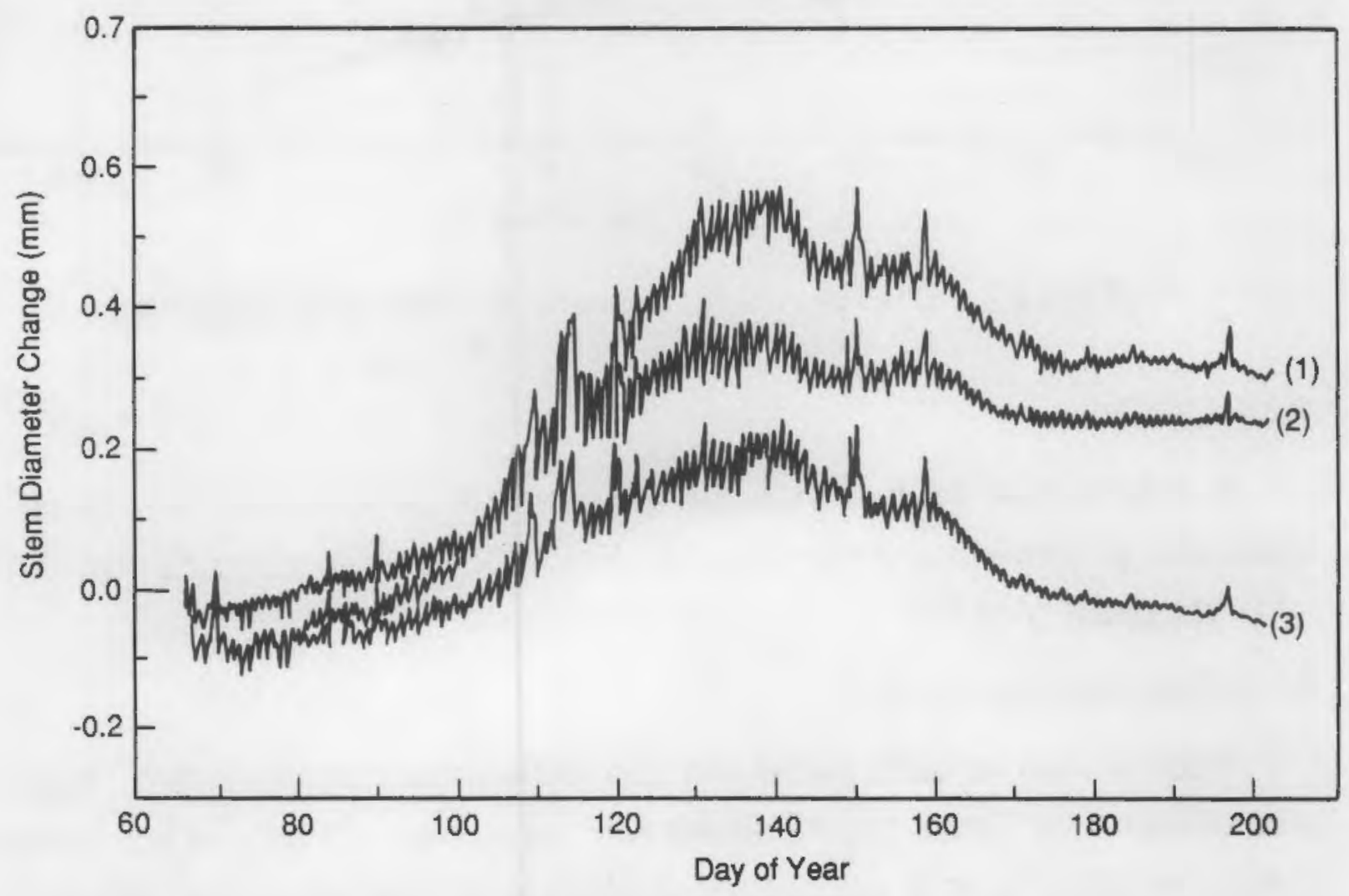

FlGURE 3.6. Change in Stem Diameter on Three A. tridentata Plants 


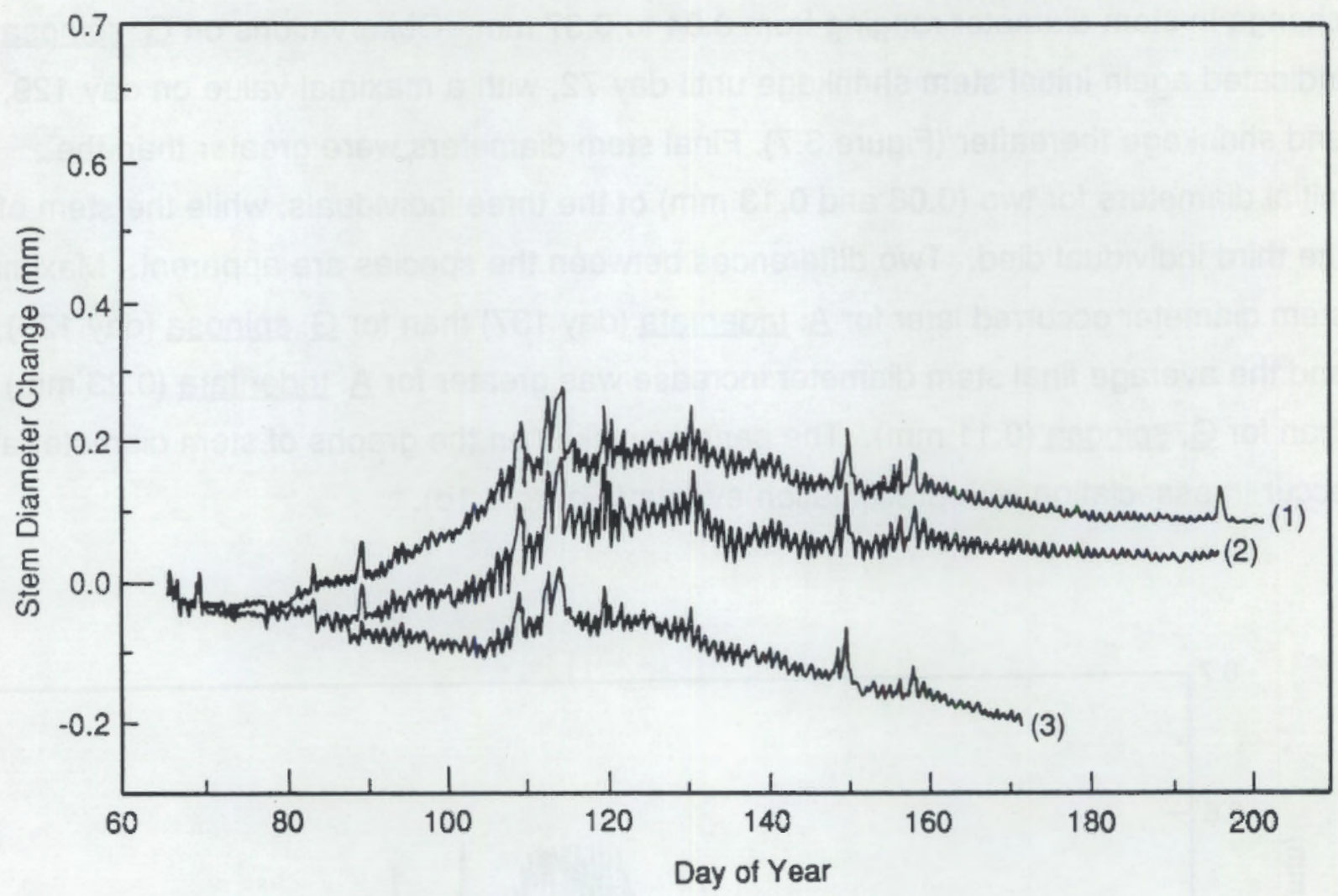

FIGURE 3.7. Change in Stem Diameter on Three G. spinosa Plants

\subsubsection{Leaf Area}

Non-destructive leaf area estimates gathered with the automated point frame indicated a percent increase from March to June of $320 \%$ for A. tridentata and $200 \%$ for $\underline{G}$. spinosa (Figure 3.8).

\subsubsection{Plant Water Relations}

Water relation variables varied with time and were species dependent. Xylem pressure potential (Figure 3.9) decreased from values near -2.0 MPa for both species in March to -6.2 MPa for $\underline{G}$. spinosa and -3.3 MPa for $\underline{A}$. tridentata in July. Values for G. spinosa were significantly lower than those of $\mathrm{A}$. tridentata. 


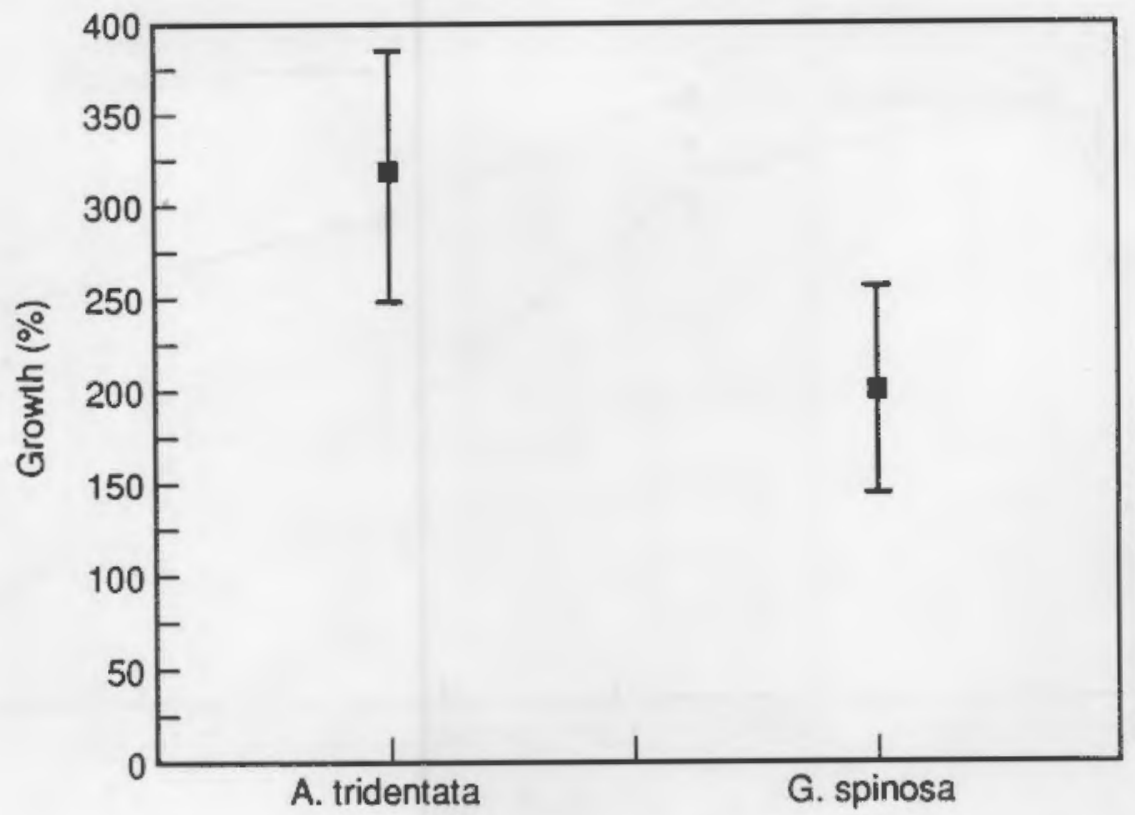

FIGURE 3.8. Average Percent Increase of Leaf Area for A. tridentata and G. spinosa. Error bars are one standard error of the mean $(n=3)$.

Osmotic potential was near -2.7 MPa for both species in March, did not change for $\underline{\mathrm{G}}$. spinosa, and increased significantly to $-2.1 \mathrm{MPa}$ for $\mathrm{A}$. tridentata in April (Figure 3.10). Osmotic potential decreased for both species after April to $-5.1 \mathrm{MPa}$ for G. spinosa and to $-4.2 \mathrm{MPa}$ for $\mathrm{A}$. tridentata.

Turgor pressure varied between 0.5 and $1.5 \mathrm{MPa}$ over the period for A. tridentata, while it decreased from 1.4 to $-1.1 \mathrm{MPa}$ for $\mathrm{G}$. spinosa from March to July (Figure 3.11).

\subsubsection{Plant Gas Exchange}

Gas exchange characteristics changed with time and generally were different for the two species. Net photosynthesis decreased with time for both species with values near $18 \mu \mathrm{mol} \mathrm{CO} 2 \mathrm{~m}^{-2} \mathrm{~s}^{-1}$ and $16 \mu \mathrm{mol} \mathrm{CO} \mathrm{CO}_{2}-2 \mathrm{~s}^{-1}$ in March to $-2 \mu \mathrm{mol} \mathrm{CO} \mathrm{CO}_{2} \mathrm{~m}^{-2} \mathrm{~s}^{-1}$ and $0.5 \mu \mathrm{mol} \mathrm{CO} \mathrm{Cm}^{-2 \mathrm{~s}^{-1}}$ in July for $\mathrm{A}$. tridentata and $\underline{\mathrm{G}}$. spinosa, respectively (Figure 3.12). 


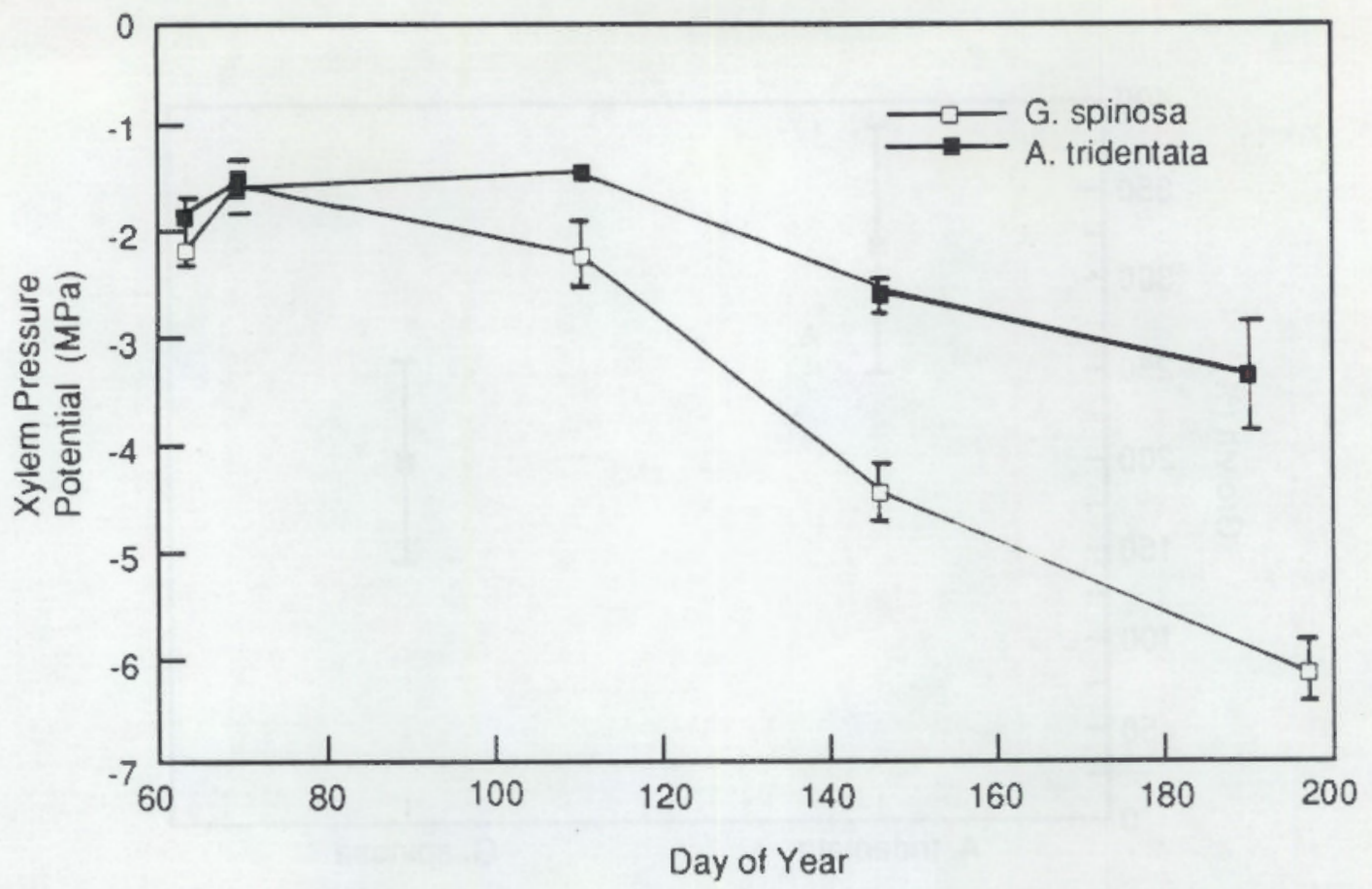

FIGURE 3.9. Average Xylem Pressure Potential for $\mathrm{A}$. tridentata and $\mathrm{G}$. spinosa at Midday from March to July. Error bars are $95 \%$ confidence intervals $(n=6)$.

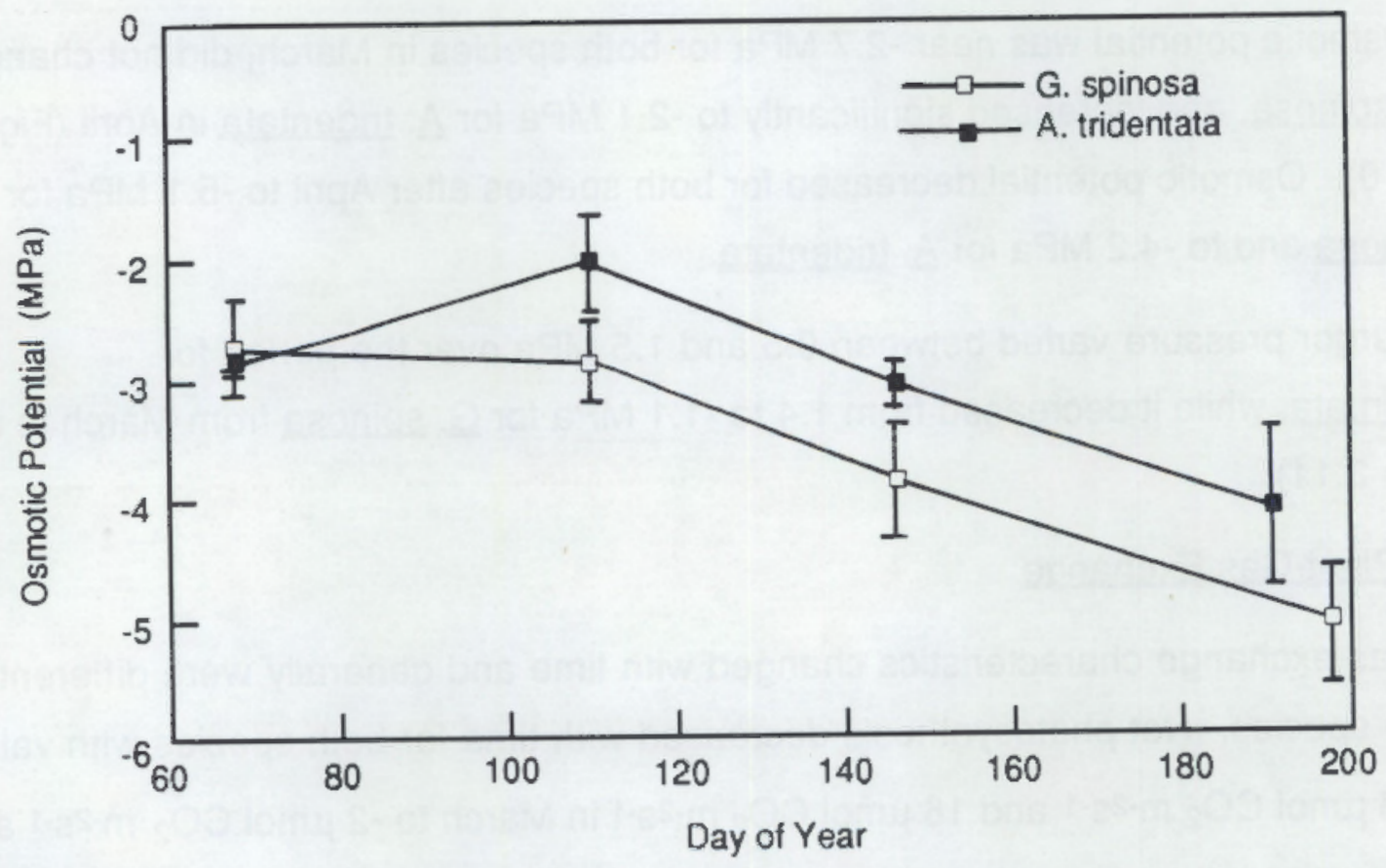

FIGURE 3.10. Average Osmotic Potential for $\underline{A}$. tridentata and $\underline{G}$. spinosa at Midday from March to July. Error bars are $95 \%$ confidence intervals $(n=6)$. 


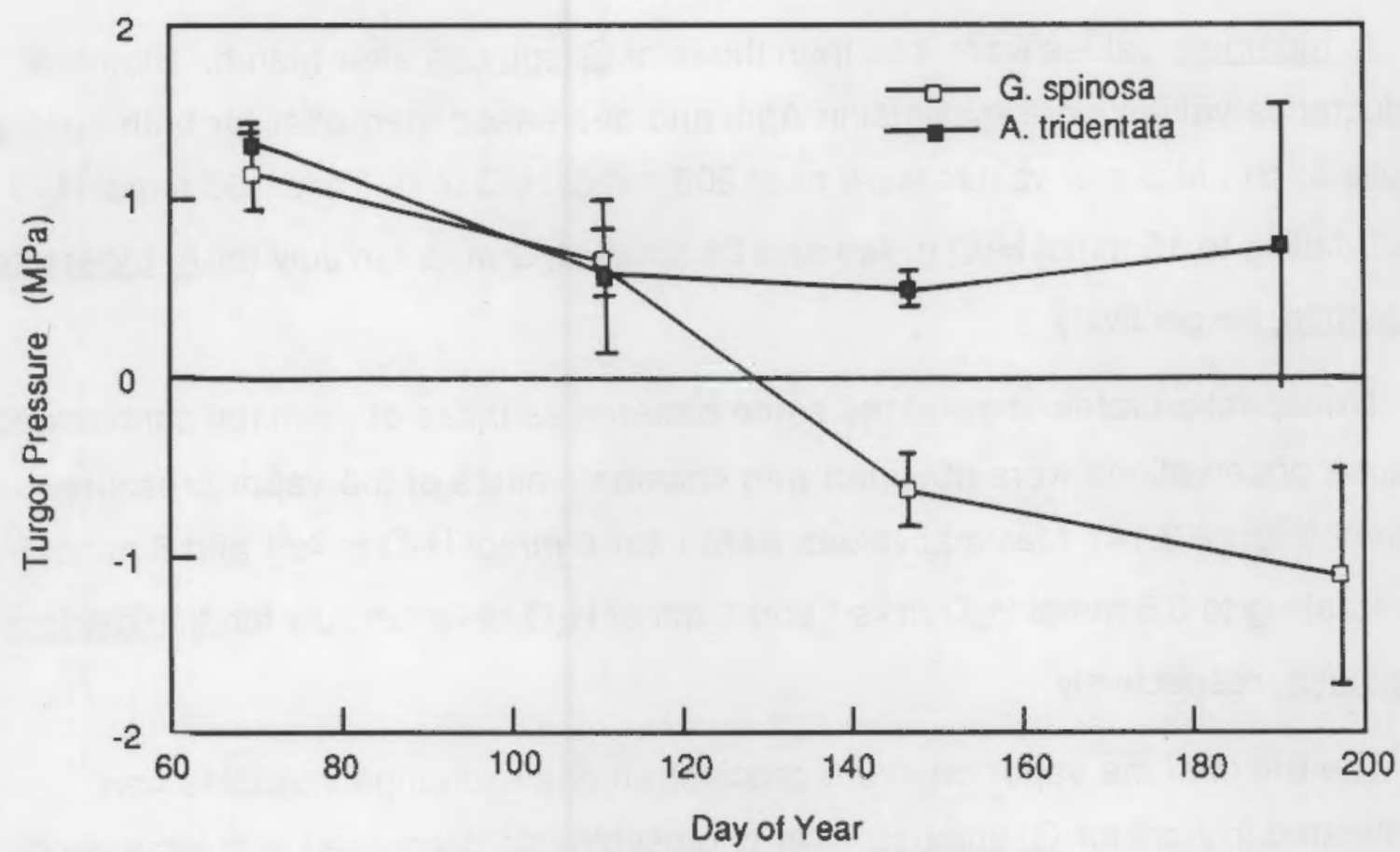

FIGURE 3.11. Average Turgor Pressure for $\mathrm{A}$. tridentata and $\underline{\mathrm{G}}$. spinosa at Midday from March to July. Error bars are $95 \%$ confidence intervals $(n=6)$.

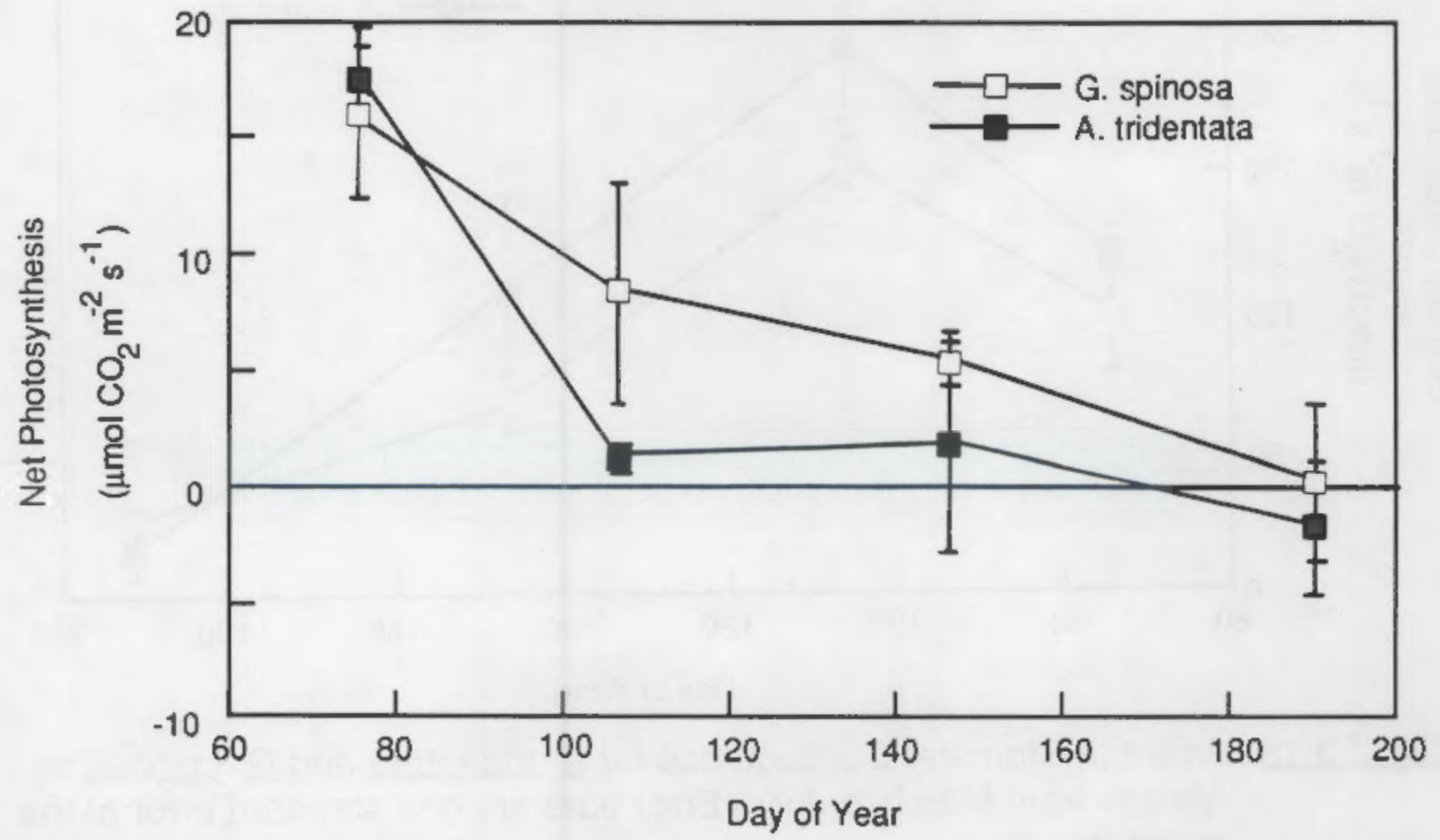

FIGURE 3.12. Average Net Photosynthesis for $A$. tridentata and $\underline{G}$. spinosa at Midday from March to July. Error bars are one standard error of the mean $(n=3)$. 
A. tridentata values were less than those of $\underline{G}$. spinosa after March. Stomatal conductance values were maximal in April and decreased thereafter for both species (Figure 3.13). Maximal values were near $200 \mathrm{mmol} \mathrm{H}_{2} \mathrm{O} \mathrm{m}-2 \mathrm{~s}^{-1}$ and $150 \mathrm{mmol} \mathrm{H}_{2} \mathrm{O}$ $\mathrm{m}-2 \mathrm{~s}^{-1}$, falling to $15 \mathrm{mmol} \mathrm{H}_{2} \mathrm{O} \mathrm{m}-2 \mathrm{~s}^{-1}$ and $25 \mathrm{mmol} \mathrm{H}_{2} \mathrm{O} \mathrm{m}-2 \mathrm{~s}^{-1}$ in July for $A$. tridentata and G. spinosa respectively.

Transpiration rates showed the same patterns as those of stomatal conductance because observations were obtained with constant values of the vapor pressure gradient (Figure 3.14). Maximal values were near $6 \mathrm{mmol} \mathrm{H}_{2} \mathrm{O} \mathrm{m}-2 \mathrm{~s}^{-1}$ and $5 \mathrm{mmol} \mathrm{H}_{2} \mathrm{O}$ $\mathrm{m}^{-2} \mathrm{~s}^{-1}$, falling to $0.5 \mathrm{mmol} \mathrm{H}_{2} \mathrm{O} \mathrm{m}-2 \mathrm{~s}^{-1}$ and $1 \mathrm{mmol} \mathrm{H}_{2} \mathrm{O} \mathrm{m}-2 \mathrm{~s}^{-1}$ in July for $\underline{A}$. tridentata and G. spinosa, respectively.

The effect of the vapor pressure gradient on gas exchange variables was investigated in April for $\underline{G}$. spinosa. Net photosynthesis decreased with increasing

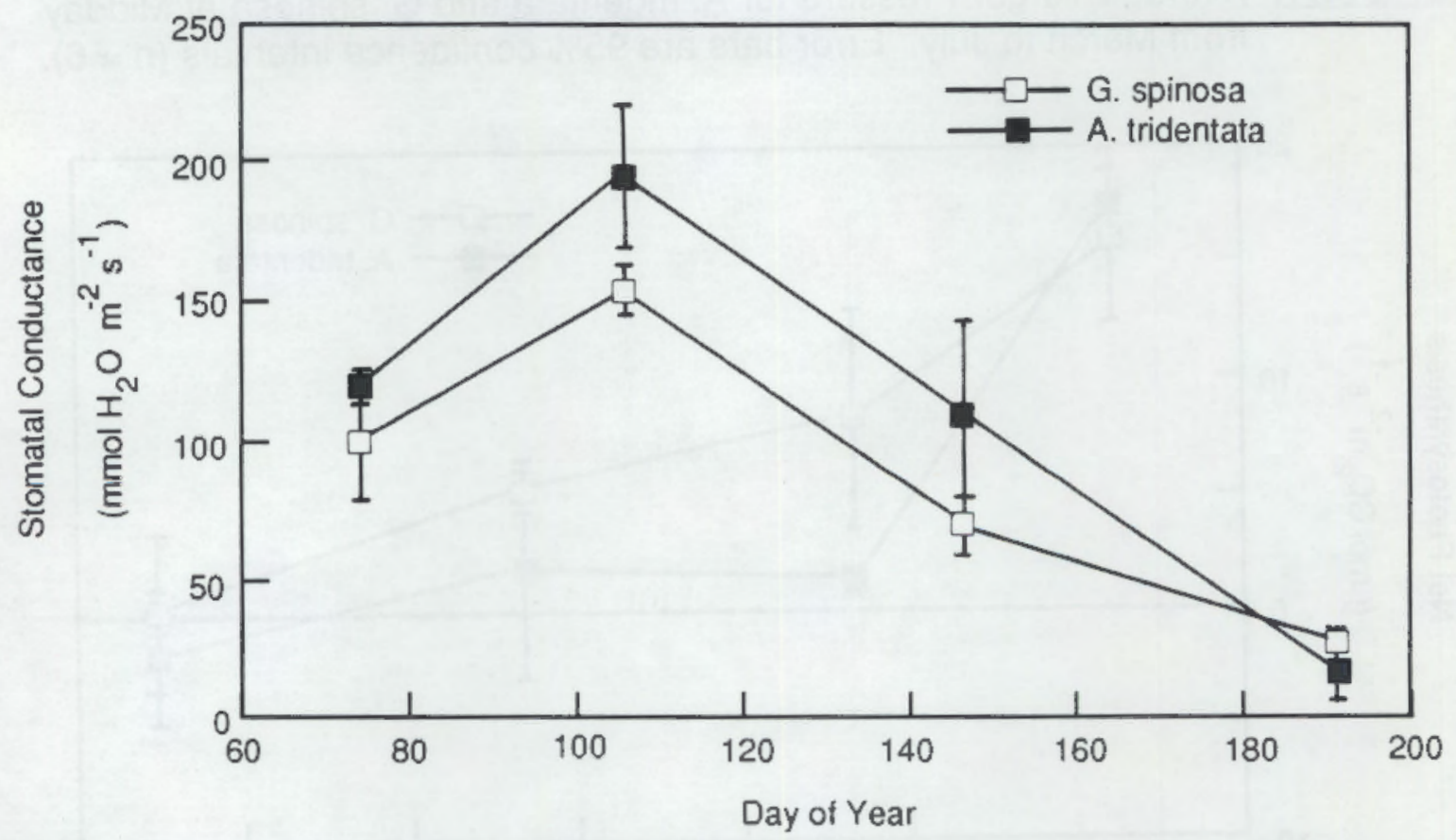

FIGURE 3.13. Average Stomatal Conductance for A. tridentata and G. spinosa at Midday from March to July. Error bars are one standard error of the mean $(n=3)$. 


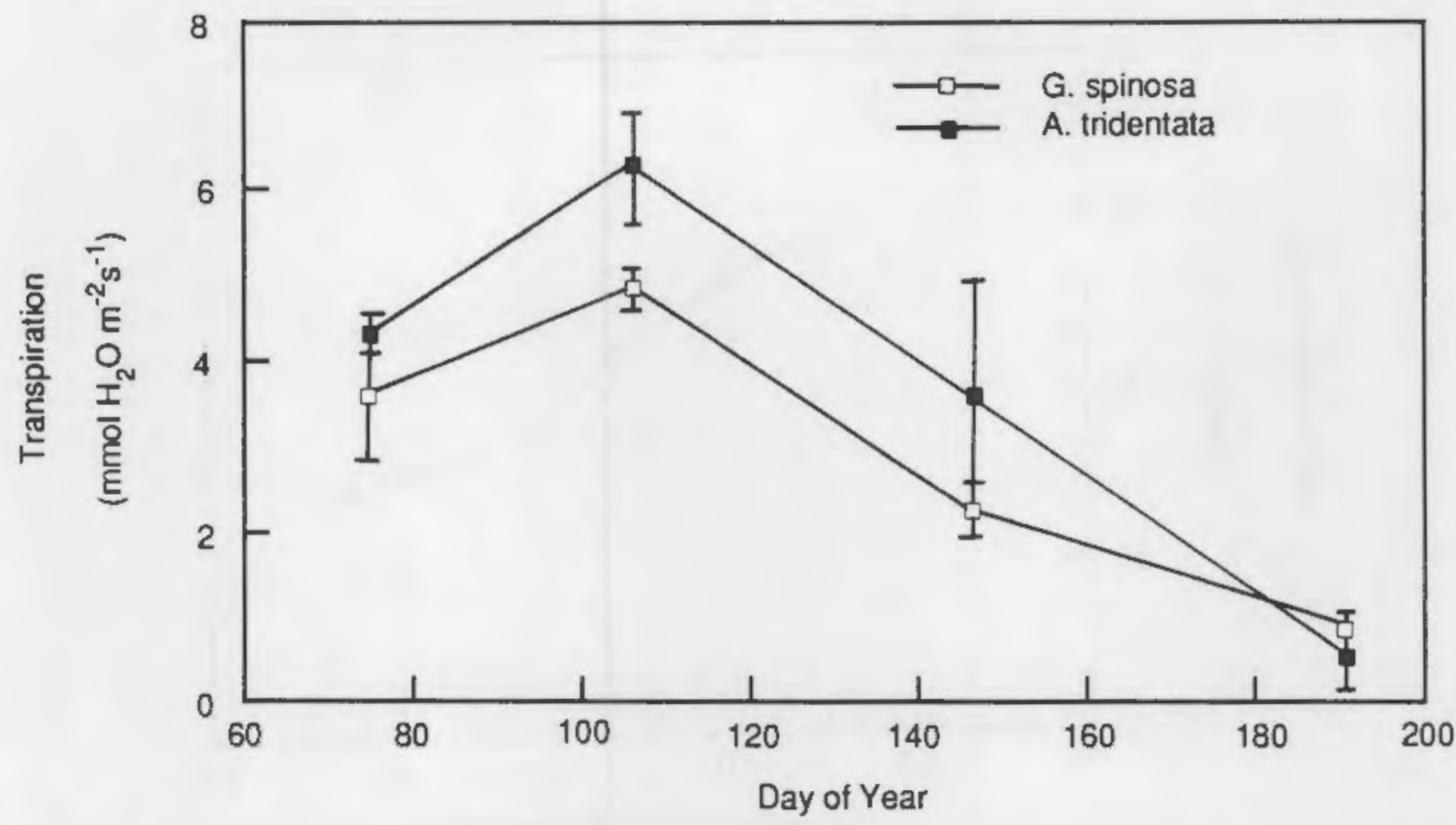

FIGURE 3.14. Average Transpiration for $\underline{A}$. tridentata and $\underline{G}$. spinosa at Midday from March to July. Error bars are one standard error of the mean $(n=3)$.

vapor pressure gradient with a maximal value near $25 \mu \mathrm{mol} \mathrm{CO} 2 \mathrm{~m}^{-2} \mathrm{~s}^{-1}$ to $17.5 \mu \mathrm{mol}$ $\mathrm{CO}_{2} \mathrm{~m}^{-2} \mathrm{~s}^{-1}$ at the highest gradient (Figure 3.15).

Stomatal conductance decreased nonlinearly with increasing vapor pressure gradient (Figure 3.16). Stomatal conductance decreased little when the vapor pressure gradient was less than $0.8 \mathrm{KPa}$ with values near $390 \mathrm{mmol} \mathrm{H}_{2} \mathrm{O} \mathrm{m}-2 \mathrm{~s}^{-1}$, values decreased linearly to $190 \mathrm{mmol} \mathrm{H}_{2} \mathrm{O} \mathrm{m}-2 \mathrm{~s}^{-1}$ between 0.8 and $1.6 \mathrm{KPa}$ of vapor pressure gradient, and values fell slightly when the vapor pressure gradient increased to $2.3 \mathrm{KPa}$.

Transpiration rates increased with increasing vapor pressure gradient, rising from $2 \mathrm{mmol} \mathrm{H}_{2} \mathrm{O} \mathrm{m}-2 \mathrm{~s}^{-1}$ to $4 \mathrm{mmol} \mathrm{H}_{2} \mathrm{O} \mathrm{m}-2 \mathrm{~s}^{-1}$ (Figure 3.17). As the vapor pressure gradient increased, internal $\mathrm{CO}_{2}$ concentrations gradually fell from 240 to 175 ppm (Figure 3.18). As the vapor pressure gradient increased, water-use efficiency fell rapidly from $11 \mu \mathrm{mol} \mathrm{CO} / 2 / \mathrm{mmol} \mathrm{H}_{2} \mathrm{O}$ to $4.5 \mathrm{mmol} \mathrm{CO} / \mathrm{mmol} \mathrm{H}_{2} \mathrm{O}$ (Figure 3.19). 


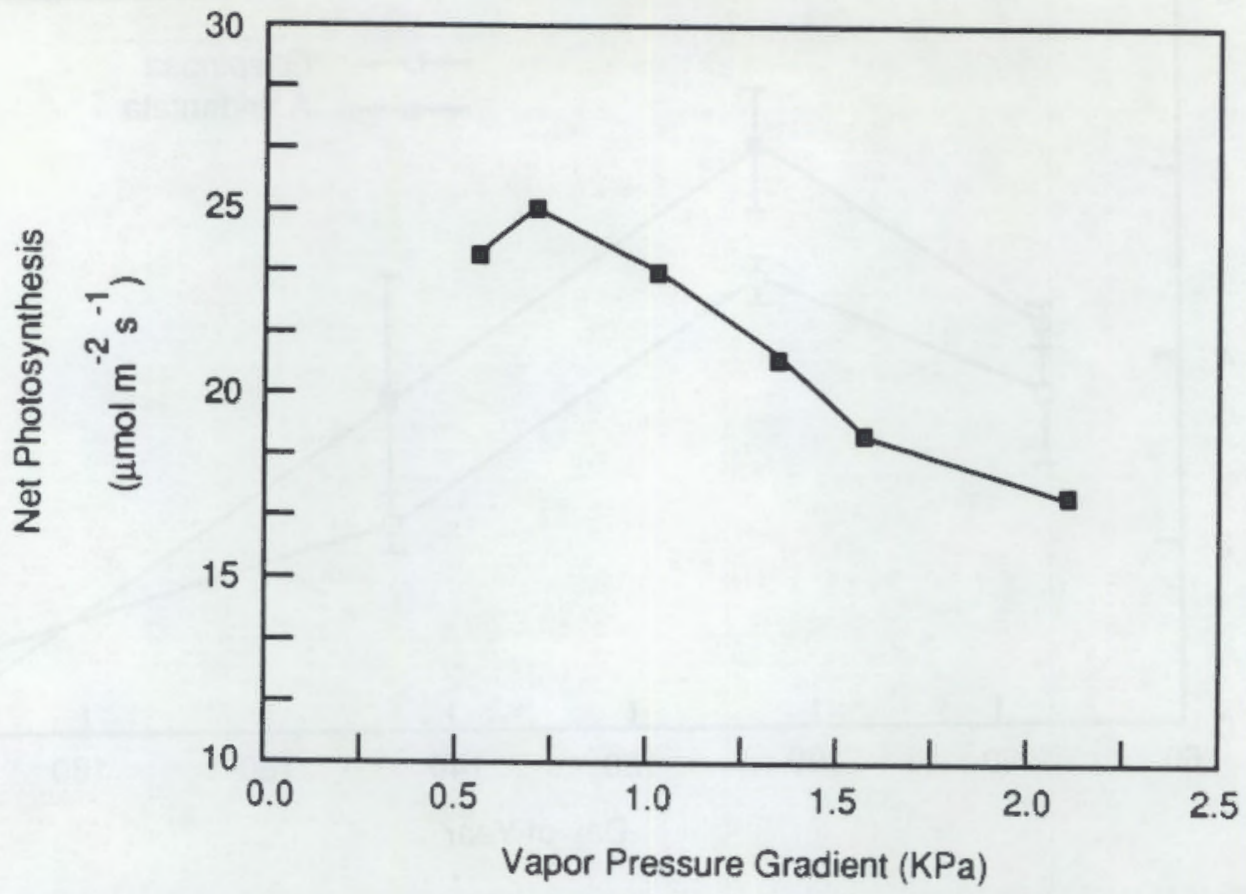

FIGURE 3.15. Effect of Vapor Pressure Gradient on Net Photosynthesis of $\underline{\mathrm{G}}$. spinosa

\subsection{DISCUSSION}

The purpose of the study at McGee Ranch was to provide some basic information on the dynamics of the dominant plants found there. The ultimate value of this information will be to improve the UNSAT-H code, which predicts soil water dynamics. A good predictive code includes plant characteristics that determine transpiration rates. Such characteristics can be broadly categorized into two groups, plant size and water relationships. Plant size is a strong determinant of transpiration with large plants transpiring more water than small plants. To predict plant size, it is necessary to understand growth processes. To this end, we obtained data on leaf-area dynamics, phenology, stem growth, and net photosynthesis. Plant-water relations are plant characteristics other than size that determine transpiration rates and include a wide range of plant characteristics, which generally are related to a species' ability to transpire water given soil type, availabilty of soil water, rooting characteristics, atmospheric determinants of transpiration through leaves, and internal mechanisms of leaves that allow them to remain active under drought conditions. This last 


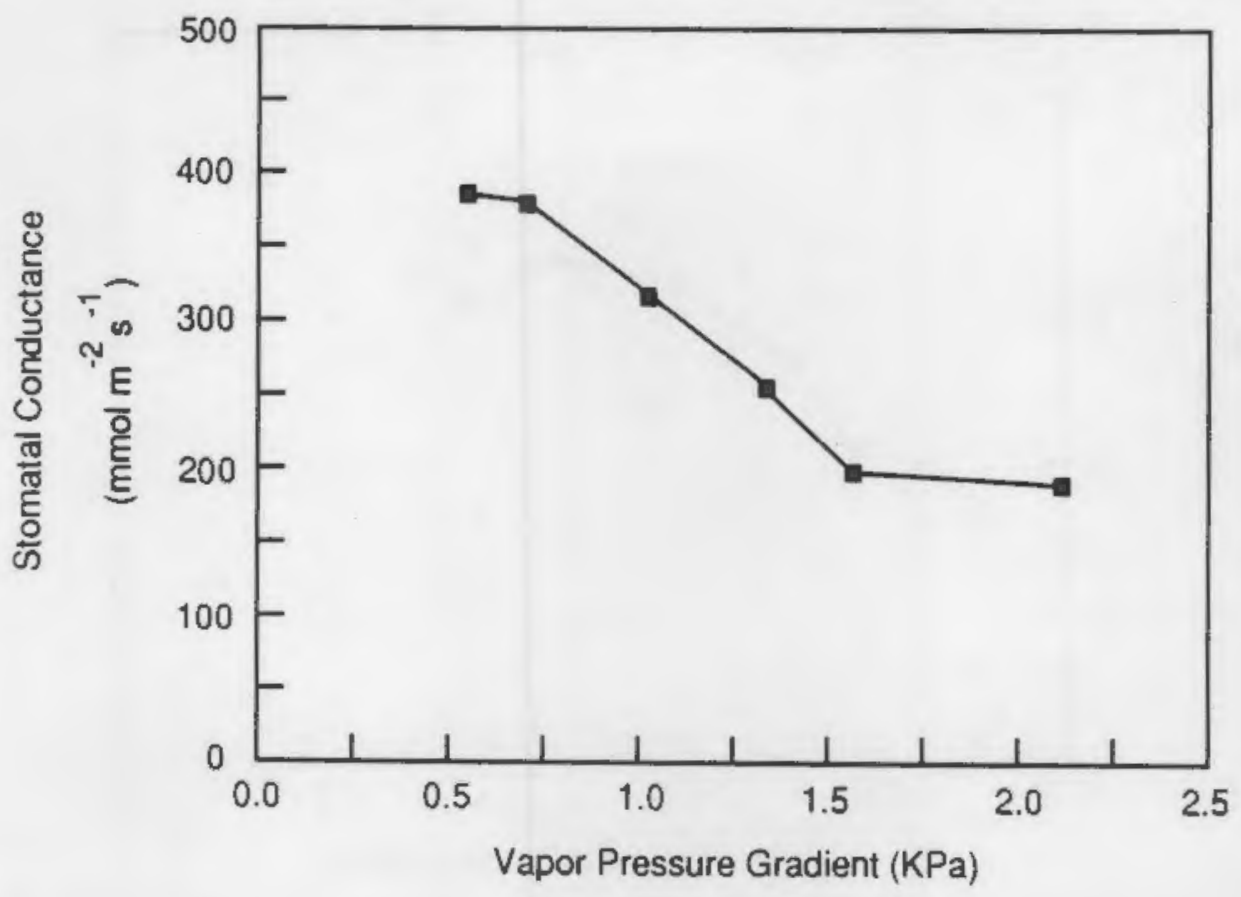

FIGURE 3.16. Effect of Vapor Pressure Gradient on Stomatal Conductance of G. spinosa

characteristic is most relevant to arid land plants. Most agronomic species cannot survive soil water potential at less than $-1.5 \mathrm{MPa}$. Under drought conditions, agronomic species die because they can no longer remove water from the soil. In contrast, many arid land plants are capable of remaining active at much lower soil water potentials. Information on the plant water relations of these species was obtained by collecting data on soil water contents, plant water potential, and transpiration. In the field, it is not possible to completely separate plant water relations from growth, because a plant must have adequate water to grow or must be able to osmotically adjust to use water held at low potential in the soil. The separation made is only for convenience in this discussion.

\subsubsection{Growth Characteristics}

Two elements of growth are most relevant to the process of transpiration, canopy structure, or canopy leaf area, and root exploration. In this study, only leaf-area dynamics were examined directly and only for partial canopies. No attempt was made 


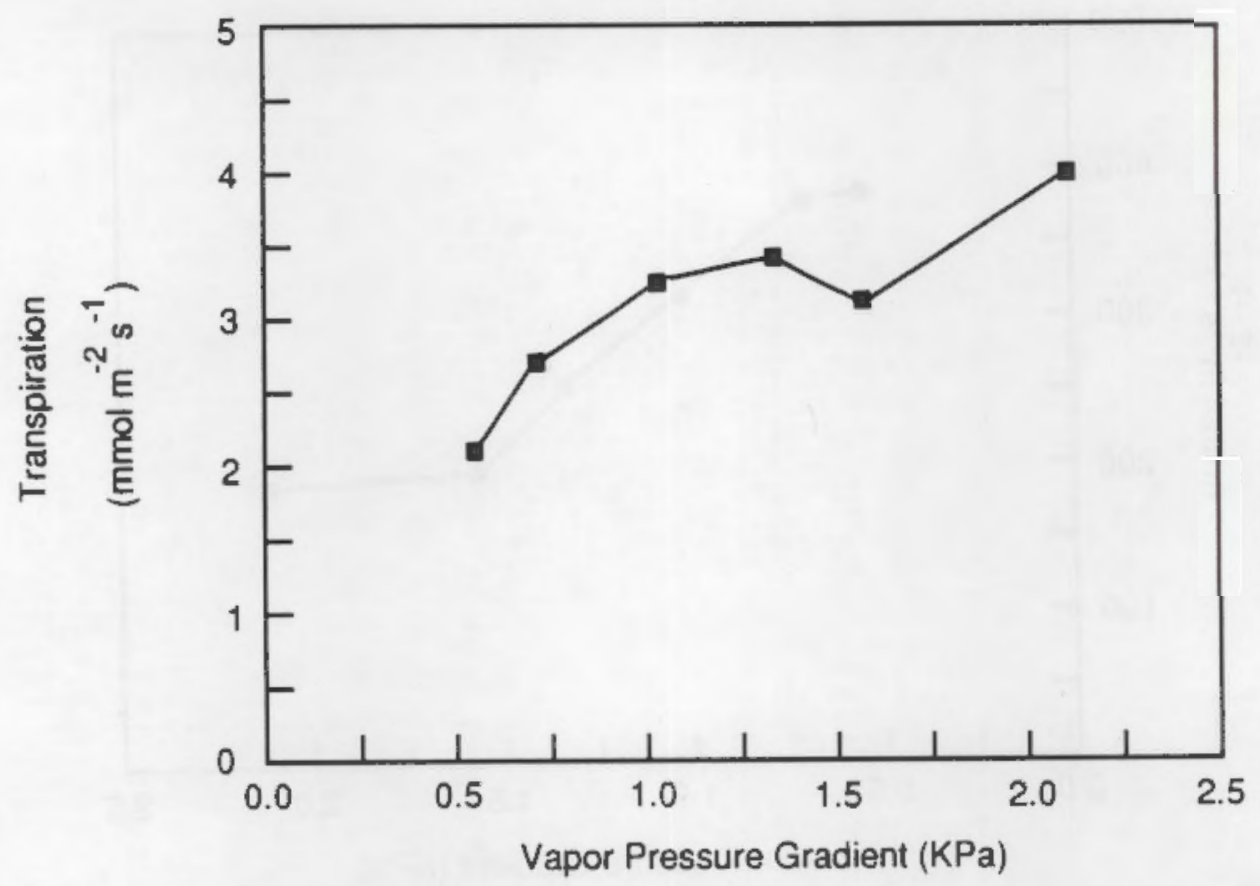

FIGURE 3.17. Effect of Vapor Pressure Gradient on Transpiration of G. spinosa

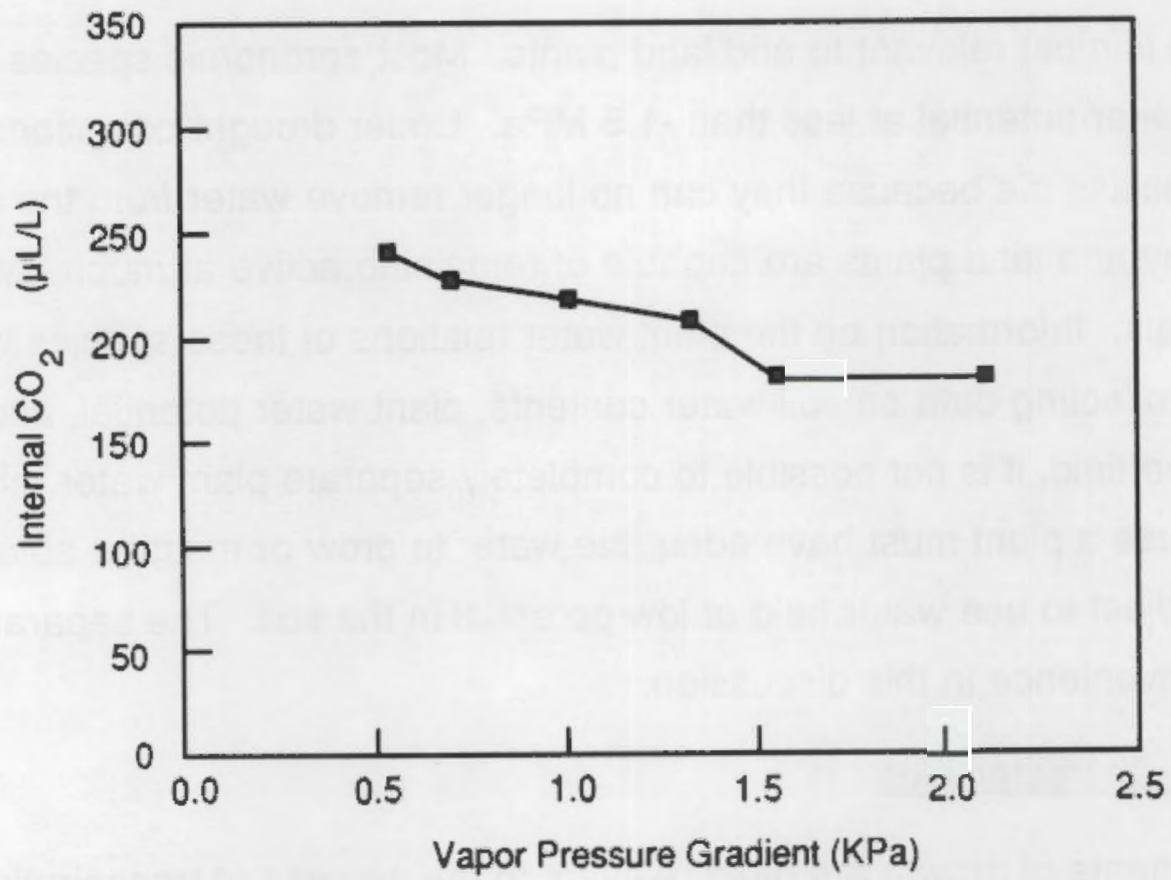

ElGURE 3.18. Effect of Vapor Pressure Gradient on Internal $\mathrm{CO}_{2}$ of $\mathrm{G}$.spinosa 


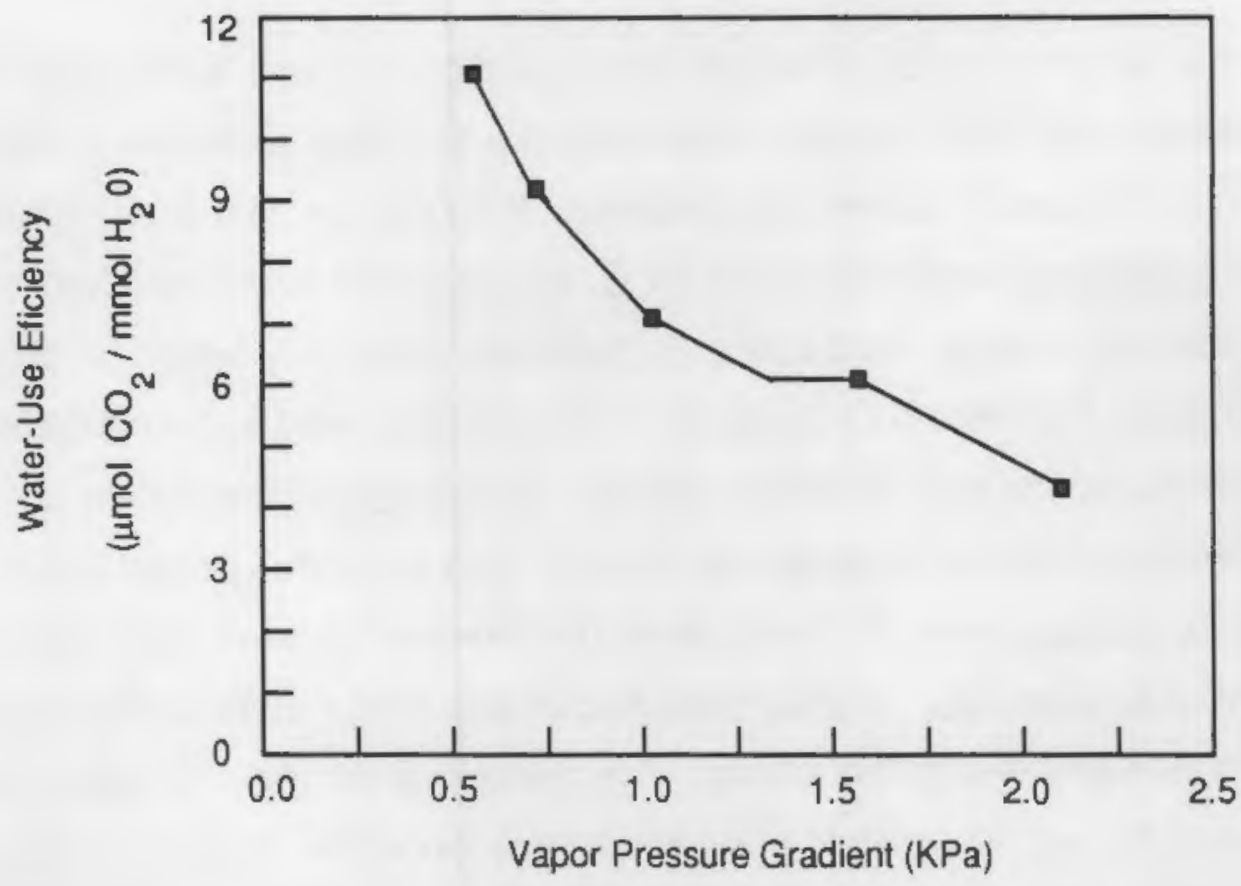

FIGURE 3.19. Effect of Vapor Pressure Gradient on Water-Use Efficiency of G. spinosa

to examine root dynamics, although some inferences about root exploration can be drawn from soil water profiles. Because leaf area is a central plant variable, it is standard practice to express transpiration rates and net photosynthetic rates by leaf area instead of by leaf biomass. For transpiration modeling purposes, it is best to understand leaf-area dynamics at the whole plant level rather than on a smaller level such as stem tips. This is because whole plant transpiration is easier to relate to whole plant leaf area estimates than reconstruct ing whole plant transpiration from the sum of foliage elements such as stem tips, older foliage, and floral parts. The problem with whole plant approach is that transpiration rates from these differing tissue types are different and would require intensive study of each tissue type. Estimates of whole plant transpiration based on the new growth of stem tips are not reliable. Although this process has been followed for many years, it is labor intensive, complex, and not always accurate.

The recent availability of accurate automated point frames (Caldwell et al. 1983) has made it possible to nondestructively estimate whole plant leaf area for relatively 
small plants as in this study. It will be more practical to relate whole plant transpiration rates to whole plant leaf area estimates because both measures are at the same scale, although such relationships will be empirical. In this study, leaf area increased by $320 \%$ for $A$. tridentata and only $200 \%$ for $\underline{G}$. spinosa from March to June. It is hypothesized that, on a whole plant basis, $\underline{A}$. tridentata potentially would be able to transpire more water than would $\mathrm{G}$. spinosa. This possibility was further supported by the differing phenological traits of these species. G. spinosa is deciduous and displays only one type of leaf during the growth period. The estimates of leaf area obtained in March for $\underline{G}$. spinosa were obtained when the new leaves were very small compared with those of $A$. tridentata. $A$. tridentata in contrast, has a more complex phenology with deciduous and evergreen leaves. The deciduous leaves of $\underline{A}$. tridentata rise in the early spring, but fall again in early summer when water stress increases beyond an as of yet unknown level. The evergreen leaves, it is assumed, remain year-round, although their longevity is not really known. The March estimates of leaf area for A. tridentata were obtained when most leaves present were evergreen, which constituted considerably more leaf area than was present on $\underline{G}$. spinosa at the time. The percentage increase of leaf area for $\underline{A}$. tridentata was higher than that for $\underline{G}$. spinosa, but does not consider the higher initial leaf area of $\underline{A}$. tridentata; thus, the final leaf area of $A$. tridentata was proportionately much higher than that of $G$. spinosa. Future work should examine leaf-area dynamics for entire canopies as opposed to partial canopies as was done in this study so that absolute estimates of canopy leaf area can be determined. Such data will be more readily integrated into growth submodels of the transpiration process.

Because estimating whole plant leaf area with the automated point frame is labor intensive, the CERES stem diameter measurement system was used to obtain more sensitive estimates of growth. Data from the CERES units are gathered continuously and thus can yield information about when growth begins, becomes maximal, and ends. It is hypothesized that stem diameter increments will be correlated with leaf area increments, but this is as of yet untested. Stem diameter measurements indicate how much growth has occurred over a period of time, but only in the context of how much 
wood has been added to the stem. Another complicating factor with these measurements is that it is likely that some of the stem increment is a result of the hydration state of the stem tissue and not simply carbon gain as wood increments. Measurements indicate stem diameter increases began near day 72 for both species with the rate of increase for $\underline{A}$. tridentata being greater than that for $\underline{G}$. spinosa, which allows a date to be assigned to initiation of growth. Increases in stem diameter continued a week longer for $\underline{A}$. tridentata than for $\underline{G}$. spinosa, which could mean that $\underline{A}$. tridentata continued to add wood to the stems, or that its stems remained hydrated longer than those of $\mathrm{G}$. spinosa. The separation of growth from hydration status would require a careful experiment where wet and dry weights of stem pieces were measured along with stem diameters. The final stem diameter measurements probably reflect the net amount of wood added to the stems over the course of the growth period. It was found that A. tridentata had greater final stem diameters than did $\underline{G}$. spinosa, which is indicative of greater growth rates.

\subsubsection{Plant Gas Exchange}

Leaf area and stem diameter are the results of growth processes and can most likely be empirically related to several environmental variables. They do not yield information specifically related to the causes of growth. To construct mechanistic models of leaf area development, it is desirable to obtain information on the more basic causes of growth, one of which is carbon gain or net photosynthesis. Data on net photosynthesis were obtained monthly for both species under standard conditions to determine how net photosynthesis changes through the growing season. Rates declined for both species with rates of $\underline{G}$. spinosa higher than those of $\underline{A}$. tridentata. Because temperature, relative humidity, $\mathrm{CO}_{2}$, and light were constant for these observations, other factors must account for the observed pattern in net photosynthesis. A strong determinant of net photosynthesis is stomatal conductance, or how open the stomates are. Stomatal conductance decreased from April to July, which could account for some of the decrease in net photosynthesis over that period. Stomatal conductance cannot account for all the variation in net photosynthesis, 
though, because net photosynthesis decreased from March to April, while stomatal conductance increased. Older leaves generally have lower rates of net photosynthesis, which could account for some of the observed decrease in rates. The decrease in xylem pressure potentials observed over the period tend to be associated with decreases in net photosynthesis and may account for some of the variation. Another factor that could account for some of the variation in rates may be the environmental conditions experienced by the rest of the canopy, which could then be translated to the stem material used to assess net photosynthesis. Although it is not known for G. spinosa, most plants, including A. tridentata, exhibit a reduction in midday net photosynthetic rates associated with high temperature and low relative humidity, which occurred when these data were collected.

Because one goal of this plant research is to develop models of growth, work was initiated to determine the relationship of environmental variables to net photosynthesis. The relationship was examined between the vapor pressure gradient around the leaves to net photosynthesis. This experiment was successful for $\underline{G}$. spinosa, but not for $A$. tridentata. With $A$. tridentata it was not possible to create a humid atmosphere in the chamber, and thus, to generate a complete relationship between vapor pressure gradient and net photosynthesis. A. tridentata did not transpire enough water into the chamber to appreciably humidify it, regardless of how much leaf material was in the chamber. A decreasing relationship was found between the vapor pressure gradient and net photosynthesis for $\mathrm{G}$. spinosa. This is most likely because of the decrease in stomatal conductance and associated reduction of internal $\mathrm{CO}_{2}$, which limits the supply of $\mathrm{CO}_{2}$ for photosynthesis.

The other aspect of plant growth of significance to transpiration is root growth. When water is limiting, the growth of roots toward water can sustain growth and continue the process of transpiration. Root growth was not directly monitored, but some inferences can be drawn about rooting behavior from soil water profiles where holes were placed around individual shrubs. The main difference between A. tridentata and $\mathrm{G}$. spinosa was the difference in soil water content between 175 and 
$225 \mathrm{~cm}$. For $A$. tridentata, little difference was evident in soil water content between these two depths, while significantly more water was found at $225 \mathrm{~cm}$ than at $175 \mathrm{~cm}$ for $\mathrm{G}$. spinosa. This is attributed to a lack a roots for $\mathrm{G}$. spinosa at $225 \mathrm{~cm}$, and consequently, water could not be in this zone. Whether roots of $\mathrm{G}$. spinosa are present at this depth would have to be determined. It is possible that soil effects could account for the observed difference.

\subsubsection{Plant Water Relations}

Although plant size (roots and leaf area) are direct determinants of a plant's ability to withdraw water from the soil, plant water relations play a significant role, especially for arid land plants, in determining transpiration rates. Although it was concluded that the rooting depth of $\mathrm{G}$. spinosa is most likely less than that of $A$. tridentata, another characteristic of soil water depletion patterns can be related to plant water status. In July, it was observed that in the upper zones $(30 \mathrm{~cm})$ the soil water content around $\mathrm{G}$. soinosa $(5 \%)$ was significantly less than that around A. tridentata $(7 \%)$. This difference is because of the substantially more negative xylem pressure potential of $\underline{G}$. spinosa compared with $\underline{A}$. tridentata. In July, the xylem pressure potential of $\underline{G}$. spinosa was near $-6.2 \mathrm{MPa}$, while that of $\underline{A}$. tridentata was only $-3.3 \mathrm{MPa}$. The consequence of this is that $\mathrm{G}$. spinosa has the ability to remove water from the soil at lower soil water potentials than does $A$. tidentata and may be the reason for the observed lowering of soil water content around $\mathrm{G}$. spinosa compared with that around $A$. tridentata.

Plant water relations, narrowly defined, refers to water potentials within the plant and how the plant responds to them. As described earlier, agronomic plants usually cannot tolerate soil water potentials less than $-1.5 \mathrm{MPa}$, which means that the plant has a xylem pressure potential near -1.5 MPa. Arid land plants, in contrast, can tolerate much lower soil water potentials by adjusting cellular osmotic concentrations. The xylem pressure potential of $G$. spinosa fell to much lower values than for A. tidentata by July, yet both species maintained turgor and physiological activity. The hypothesis was that osmotic potential values would be similarly different for the two 
species to maintain turgor pressure values greater than zero. Although the osmotic potential of $\mathbf{G}$. spinesa was lower than that of $A$. tidentata after March, the levels were not low enough to yield turgor pressure values greater than zero after April. Turgor pressure values were the same for both species in March and April, but were significantly different after that. For a plant to maintain physiological activity, it must maintain a positive turgor pressure, which was observed in $\underline{A}$. tridentata. Negative turgor pressure values have been observed in other arid land plants and are usually explained as a methodological problem. This phenomena is usually attributed to a high level of symplastic water, which, when the plant is ground for osmotic potential measurement, dilutes the osmotica yielding artificially high values. This is probably the case for $\underline{G}$. spinesa and not for $\underline{A}$. tridentata. It is true that $\underline{G}$. spinesa was physiologically active at all times during this investigation and if its true turgor pressure is assumed to be 0.5 to $1.0 \mathrm{MPa}$, then it can be hypothesized that its true osmotic potential was closer to -6.7 than to-7.2 $\mathrm{MPa}$. This technique problem has no easy solution, but is a topic of current research. Finally, the higher xylem pressure potential values of $A$. tridentata compared with $G$. spinosa in July may be because of differing rooting depths. If it is assumed that the roots of $A$. thidentata are deeper than those of G. spinosa, then it has access to a greater reservoir of deep water. The withdrawal of such water may require less tension in the plant. 


\subsection{EUTURE WORK}

The whole plant gas exchange system will be used in spring 1989 to address hypotheses addressed in Waugh and Link (1988). To more effectively address these hypotheses, it is proposed that replicate chambers be constructed. Future work at McGee Ranch should focus on model development and some characterization. The relationship between gas exchange processes and environmental driving variables also should be systematically developed. This will require some modifications to the gas exchange system used this year. In addition, more data need to be gathered on whole plant leaf area dynamics and soil water content. 


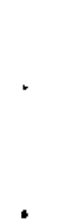




\subsection{BEFEBENCES}

Beedlow, P. A., D. S. Daly, and M. E. Theide. 1986. "A New Device for Measuring Fluctuations in Plant Stem Diameter: Implications for Monitoring Plant Response." Environ. Mon. Assess, 6: 277-282.

Caldwell, M. C., T. J. Dean, R. S. Nowak, R. S. Dzurec, and J. H. Richards. 1983. "Bunchgrass Architecture, Light Interception, and Water Use Efficiency: Assessment by Fiber Optic Point Quadrats and Gas Exchange." Oecologia 59:178-184.

Link, S. O., and W. J. Waugh. 1989. Evapotranspiration Studies for Protective Barriers: Experimental Plans. PNL-6899, Pacific Northwest Laboratory, Richland, Washington.

Scholander, T. F., H. T. Hammel, E. D. Bradstreet, and E. A. Hemmingsen. 1965. "Sap Pressure in Vascular Plants." Science 148:339-346.

Waugh, W. J. and S. O. Link. 1988. Barrier Erosion Control Test Plan: Gravel Mulch. Vegetation and Soil Water Interactions. WHC-EP-0067, Westinghouse Hanford Company, Richland, Washington. 


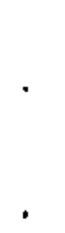




\section{DISTRIBUTION}

No. of

Copies

OFFSITE

2 DOE Office of Scientific and Technical Information

\section{ONSLTE}

8 DOE Richland Operations Office

G. J. Bracken

J. J. Broderick

R D. Freeburg

R. E. Gerton

R D. Izatt

S. M. Prestwich

G. W. Rosenwald

J. P. Sands

26 Westinghouse Hanford

Company
M. R Adams
L. C. Brown
J. W. Cammann
R. A. Carlson
H. F. Daugherty
K. A. Gasper
W. F. Heine
J. M. Henderson
G. W. Jackson
K. N. Jordan
D. S. Landeen
$R$ E. Lerch
H. E. McGuire
K. W. Owens

No. of

Copies
P. C. Payne
K. L. Petersen
S. J. Phillips
J. F. Relyea
R C. Roos
R C. Routson
W. W. Schulz
S. A. Weigman
N. R Wing
D. D. Wodrich
R. D. Wojtasek
D. E. Wood

38 Pacific Northwest Laboratory

L. L. Cadwell

M. D. Campbell

L. E. Eberhardt

J. W. Falco

M. J. Fayer

M. G. Foley

H. D. Freeman

G. W. Gee (2)

J. M. Hales

P. C. Hays

T. L. Jones

C. T. Kincaid

R. R Kirkham

G. V. Last

M. W. Ligotke

S. O. Link (5)

G. P. O'Connor

L. E. Rogers

M. A. Simmons

R. L. Skaggs 
No. of

Conies
T. L. Stewart
J. A. Sottlemyre
G. P. Steile
J. M. Thomas
R L. Treat
W. J. Waugh
R. E. Wildung
Publishing Coordination
Technical Report Files (5) 